\title{
Dawid Ślusarczyk
}

Wroctaw

\section{Muzyczna ilustracja tekstu w XVIII-wiecznych cyklach nieszpornych kompozytorów jasnogórskich ${ }^{1}$}

Jednym z centrów kultury muzycznej dawnej Rzeczypospolitej była Jasna Góra - narodowe sanktuarium, miejsce peregrynacji polskich monarchów, dostojników państwowych i kościelnych, ale także prostego ludu. Ranga klasztoru paulinów wymagała stosownej oprawy dla przybywających pątników, czego świadectwem były specjalne ceremoniarze przyjmowania dostojnych gości, rozbudowane procesje oraz przepych architektoniczny oddziałujący zwłaszcza na ubogich. Dla wszystkich odwiedzających klasztor i kaplicę z cudownym obrazem wyjątkowe znaczenie miała muzyka, którą pielgrzymi słyszeli, zbliżając się do celu (muzyka z kościelnej wieży), oraz ta wykonywana w trakcie sprawowanego kultu.

Paulińska kapela, zespół składający się w przeważającej części z muzyków świeckich, swój największy rozkwit przeżywał w XVIII wieku. Zatrudnieni w Częstochowie muzycy posiadali wysokie kwalifikacje oraz wykonywali rozległy repertuar. $\mathrm{Na}$ potrzeby zespołu kopiowano dzieła kompozytorów europejskich, ale wykonywano także utwory członków kapeli lub jej kapelmistrzów. W Archiwum Ojców Paulinów przechowywany jest bogaty zbiór dzieł obejmujący kompozycje liturgiczne i okolicznościowe, które wykonywano w kościele oraz w kaplicy, a także na zewnątrz przy okazji procesji. Cenną częścią repertuaru są utwory skomponowane na Jasnej Górze, nawiązujące do stylu, który obowiązywał w ówczesnej muzyce europejskiej.

Szczególne miejsce w życiu paulińskiej wspólnoty zajmowało odmawianie liturgii godzin², w której pewnych częściach brała udział także kapela. Muzyka

1 Artykuł prezentuje fragment badań przeprowadzonych w ramach pracy doktorskiej pt. $M u$ zyka jasnogórska jako ars oratoria. Relacje stowa i muzyki na przyktadzie XVIII-wiecznych dziet komponowanych dla kapeli oo. Paulinów w Częstochowie obronionej w Instytucie Muzykologii Uniwersytetu Jagiellońskiego w 2010 roku.

2 Zwyczaj odprawiania modlitw o określonej porze dnia, offcium divinum, był jednym z najważniejszych elementów życia monastycznego. Polegał on na regularnym odmawianiu przypisanych na dany dzień psalmów, modlitw i czytań biblijnych zawartych w brewiarzu. Początki oficjum sięgają czasów średniowiecza, kiedy święty Benedykt sformułował regułę zakonną dla nowo utworzonej wspólnoty (VI wiek). Rytm dnia w klasztorach benedyktyńskich i sprawo- 
uświetniała zwłaszcza nieszpory, które obok mszy celebrowano bardzo wystawnie ${ }^{3}$. W archiwum jasnogórskim zachowało się siedem pełnych cykli przeznaczonych na różne święta roku kościelnego. Najwcześniejsze są dziełami Eryka Briknera (1725-1753 lub 1760) oraz Wawrzyńca Neumanna (daty urodzenia i śmierci nie są znane), kolejne skomponowali Marcin Żebrowski (ok. 1710-ok. 1792) i Franciszek Pernecker (zm. ok. 1769)4.

W dalszej części przedstawione zostaną środki, za pomocą których kompozytorzy jasnogórscy ilustrowali teksty liturgiczne. Praktyka tego typu wpisuje się w tradycję zapoczątkowaną przez mistrzów renesansu, a rozwiniętą zwłaszcza w okresie baroku. Przeprowadzona analiza ukaże także indywidualne rozwiązania charakterystyczne dla warsztatu polskich twórców. W pierwszej części zostanie dokonana charakterystyka tekstów liturgicznych, których afekty oddane zostały następnie w opracowaniu muzycznym (obsada, faktura, tonacje) oraz za pomocą konstrukcji dźwiękowych (figur). W przyjętej klasyfikacji figur wykorzystano typologię zaproponowaną przez Dietricha Bartlas, polskim czytelnikom przybliżoną m.in. dzięki badaniom Tomasza Jasińskiego ${ }^{6}$.

wane tam oficjum od IX stulecia zaczęły obowiązywać we wszystkich zgromadzeniach klasztornych w Kościele Zachodnim (por. J. Harper, Formy i uktad liturgii zachodniej od X do XVIII wieku, przeł. M. Kowalska, Kraków 1997, s. 93-94). Układ i dobór tekstów w kolejnych godzinach kanonicznych podlegał częstym zmianom na przestrzeni kolejnych stuleci. Korpus nabożeństw częściowo uregulowało wprowadzenie specjalnej księgi liturgicznej, brewiarza (XI wiek), którego korekta nastąpiła kilka stuleci później, w trakcie reformy trydenckiej.

3 Celebracja vesperae, podobnie jak mszy, powierzona była kapłanom, którym towarzyszył wykwalifikowany zespół wokalno-instrumentalny. Udział wiernych sprowadzał się do biernego uczestnictwa w nabożeństwie. Począwszy od XVI wieku przełamana została hegemonia monodii gregoriańskiej na korzyść polifonicznych opracowań części nabożeństwa, czego znamienitym przykładem są Vesperae della Beata Vergine Claudio Monteverdiego - pierwszy w historii przykład opracowania wszystkich tekstów liturgicznych. W praktyce kompozytorskiej największą liczbę dzieł tworzyły nieszpory niedzielne (Vesperae de dominica) oraz świąteczne: o Matce Bożej (Vesperae de Beata Mariae Virginis), apostołach i wyznawcach (Vesperae de apostolorum, de confessore). Pod koniec następnego stulecia w architektonice nieszporów, podobnie jak w twórczości mszalnej, nastąpiły istotne zmiany pod wpływem stylów koncertującego oraz neapolitańskiego. Części psalmów i kantyku Magnificat zaczęto opracowywać jako arie i duety solowe z dużym udziałem wirtuozerii wokalnej. Wykształcone na gruncie opery środki ekspresji zaczęły obowiązywać we wszystkich gatunkach muzyki kościelnej, także w opracowaniach ostatniej części Officium divinum - komplecie. Chociaż kompozytorzy mniej chętnie tworzyli dzieła tego typu, to w historii muzyki polskiej zachowało się kilka przykładów. Na przełomie XVII i XVIII wieku Completorium występuje m.in. w twórczości Grzegorza G. Gorczyckiego czy Stanisława S. Szarzyńskiego.

4 Przyjęta chronologia ustalona została na podstawie czasu aktywności kompozytora na Jasnej Górze.

5 D. Bartel, Handbuch der musikalischen Figurenlehre, Laaber 1985.

6 T. Jasiński, Polska barokowa retoryka muzyczna, wyd. I, Lublin 2006. 


\section{Teksty vespercie $\mathrm{i}$ afekty $\mathrm{w}$ nich zawarte}

Architektonika nieszporów nie była ściśle ustalona - niektóre ogniwa ulegały zmianie w zależności od przypadającego święta. Po wstępnym wezwaniu, śpiewanym zazwyczaj w postaci chorałowej, wykonywano pięć różnych psalmów z antyfonami (zawsze Dixit Dominus jako pierwszy), następnie Capitulum oraz hymn. Nabożeństwo kończyło się kantykiem Magnificat z ceremonialnym okadzeniem ołtarza, po którym następowała kolekta i błogosławieństwo. O ile kantyk Maryi był elementem stałym, wybór psalmów oraz hymnu determinowały okoliczności wykonania, tj. przypadająca w danym dniu uroczystość. Kompozytorzy opracowywali w cyklu teksty pięciu lub większej liczby psalmów, w zależności od typu kompozycji, oraz Magnificat wieńczący dzieło.

W cyklach autorstwa twórców jasnogórskich występuje łącznie 16 tekstów psalmowych, $11 \mathrm{z}$ nich opracowane zostało przez kilku kompozytorów (por. tab. 1). Wykorzystane teksty wykazują dużą różnorodność pod względem stylistycznym.

\begin{tabular}{|l|l|}
\hline Lp. & Psalm \\
\hline 1. & Dixit Dominus Ps $110(109)$ \\
\hline 2. & Confitebor Ps $111(110)$ \\
\hline 3. & Beatus vir Ps $112(111)$ \\
\hline 4. & Laudate pueri Ps $113(112)$ \\
\hline 5 & In exitu Ps $114(113)$ \\
\hline 6. & Credidi Ps $116(115)$ \\
\hline 7. & Laudate Dominum Ps 117 (116) \\
\hline 8. & Laetatus sum Ps $122(121)$ \\
\hline 9. & In convertendo Ps 126 (125) \\
\hline 10. & Nisi Dominus Ps $127(126)$ \\
\hline 11. & Beati omnes Ps $128(127)$ \\
\hline 12. & De profundis Ps $130(129)$ \\
\hline 13. & Memento Domine Ps 132 (131) \\
\hline 14. & Confitebor Ps 138 (137) \\
\hline 15. & Domine probasti me Ps 139 (138) \\
\hline 16. & Lauda Jerusalem Ps 147 (146) \\
\hline
\end{tabular}

Tabela 1. Wykaz wykorzystanych tekstów psalmowych?7.

7 Pogrubioną czcionką zaznaczono psalmy opracowane przez kilku twórców. 
Biblijna Księga Psalmów obejmuje 150 utworów, stworzonych przez różnych autorów na przestrzeni kilkuset lat historii Izraela ${ }^{8}$. Podstawową jednostką tekstu jest werset o stałej liczbie akcentów, który dzieli się na kilka wewnętrznych członów. We wszystkich przypadkach wykorzystano łaciński przekład Biblii, którego składnia nie oddaje oryginalnego układu rytmu, charakterystycznego dla poezji w języku hebrajskim.

Biorąc pod uwagę kryteria literackie, Wilfrid Harrington' dokonał podziału twórczości psalmowej na siedem grup, który uwzględnia także charakter tekstów. Jest to jeden z możliwych podziałów Psatterza, który dla potrzeb dalszej analizy uwypukla dominujące afekty zawarte w tekstach ${ }^{10}$. Irlandzki badacz wyróżnił psalmy błagalne, dziękczynne, pochwalne, królewskie, syjońskie, psalmy królowania Jahwe oraz inne (sapiencjalne, deuteronomiczne, modlitwy). W analizowanych kompozycjach największą grupę tworzą psalmy pochwalne oraz sapiencjalne (por. tab. 2). Nie występują natomiast psalmy królowania Jahwe, jak również deuteronomiczne.

\begin{tabular}{|c|c|c|}
\hline Rodzaje psalmów & Incipity utworów literackich & Zawarte afekty \\
\hline psalmy błagalne & 1. De profundis Ps 130 (129) & smutek, cierpienie \\
\hline $\begin{array}{l}\text { psalmy } \\
\text { dziękczynne }\end{array}$ & $\begin{array}{l}\text { 1. Credidi Ps } 116 \text { (115) } \\
\text { 2. Confitebor Ps } 138 \text { (137) }\end{array}$ & radość \\
\hline $\begin{array}{l}\text { psalmy } \\
\text { pochwalne }\end{array}$ & $\begin{array}{l}\text { 1. Confitebor Ps } 111 \text { (110) } \\
\text { 2. Laudate pueri Ps } 113 \text { (112) } \\
\text { 3. In exitu Ps } 114 \text { (113) } \\
\text { 4. Laudate Dominum Ps } 117 \text { (116) } \\
\text { 5. Lauda Jerusalem Ps } 147 \text { (146) }\end{array}$ & $\begin{array}{l}\text { patos, } \\
\text { radosne uwielbienie }\end{array}$ \\
\hline
\end{tabular}

8 J. Sadzik, Wstęp, w: Księga psalmów, tłum. pol. Cz. Miłosz, Paryż 1982, s. 34.

9 W. Harrington Record of Revelation The Bible - Record of the Promise, Dublin 1965. Za: J. Sadzik, Wstęp, dz. cyt., s. 35.

${ }^{10}$ Inny podział psalmów uwzględniający kryteria gatunkowe zaproponował np. Hermann Gunkel, który wyróżnił dziewięć typów: die Hymnen, die Klagelieder des Volkes, die Königspsalmen, die Klagenlieder des einzelnen, die Danklieder des einzelen, kleinere Gattungen, prophetische Psalmen, Weisheitsdichtung, Mischungen Wechselgedichte und Liturgien. Por. Psalmen, w: Evangelisches Kirchenlexikon. Internationale theologische Enzyklopädie, hrsg. E. Fahlbusch, Göttingen 1986, t. 3, s. 1371. 


\begin{tabular}{|c|c|c|c|c|}
\hline Rodzaje psalmów & \multicolumn{2}{|l|}{ Incipity utworów literackich } & \multicolumn{2}{|c|}{ Zawarte afekty } \\
\hline psalmy królewskie & \multicolumn{2}{|l|}{$\begin{array}{l}\text { 1. Dixit Dominus Ps } 110 \text { (109) } \\
\text { 2. Memento Domine Ps } 132 \text { (131) }\end{array}$} & \multicolumn{2}{|l|}{ radość } \\
\hline psalmy syjońskie & \multicolumn{2}{|l|}{ 1. Laetatus sum Ps 122 (121) } & \multicolumn{2}{|l|}{ radość } \\
\hline \multirow[t]{2}{*}{ inne } & $\begin{array}{l}\text { 1. Beatus vir Ps } 112 \text { (111) } \\
\text { 2. Nisi Dominus Ps } 127 \text { (126) } \\
\text { 3. Beati omnes Ps } 128 \text { (127) } \\
\text { 4. Domine probasti me Ps } 139 \text { (138) }\end{array}$ & $\begin{array}{l}\text { 1. In } \\
\text { conver- } \\
\text { tendo } \\
\text { Ps } 126 \\
(125)\end{array}$ & \multirow[t]{2}{*}{ ufność } & \multirow[t]{2}{*}{$\begin{array}{l}\text { cierpienie, } \\
\text { smutek }\end{array}$} \\
\hline & sapiencjalne & modlitwy & & \\
\hline
\end{tabular}

Tabela 2. Typologia psalmów jasnogórskich wg W. Harringtona.

Psalmy pochwalne są hymnem na cześć Boga, pełnym patosu oraz uwielbienia. Utwory te wykonywano z okazji corocznych świąt obchodzonych przez pobożnych Izraelitów, aby upamiętnić wielkie dobrodziejstwa otrzymane od Stwórcy przez ich przodków ${ }^{11}$. W tekstach pojawiają się charakterystyczne eksklamacje, np. Hallelu-Jah (chwalcie Jahwe) czy Amen (niech się tak stanie). Psalmy mają budowę hymniczną o proweniencji liturgicznej, np. Laudate pueri to tzw. Hallel-wielki hymn uwielbienia.

Dziękczynienie jest uczuciem często towarzyszącym uwielbieniu, a przez to mu bliskoznacznym. W dwóch psalmach tej grupy przeważa radosny nastrój dziękczynienia osiągnięty dzięki darom otrzymanym od Boga. Autor psalmu Credidi składa Bogu dziękczynienie za odzyskane życie, w drugim tekście radość jest skutkiem wysłuchania modlitwy. W kulturze hebrajskiej psalmy miały głównie zastosowanie liturgiczne, korzystano $\mathrm{z}$ nich $\mathrm{w}$ tracie ceremonii sprawowanych w świątyni o charakterze prywatnym i państwowym.

Nadrzędnym afektem w dwóch psalmach królewskich jest radość, której przyczyną były pomyślne wydarzenia związane z osobą monarchy. Utwory tego typu wykonywano pierwotnie podczas uroczystości dworskich, takich jak namaszczenie nowego króla, jego zaślubiny czy też po zwycięskiej bitwie.

Psalm należący do kolekcji syjońskiej jest pieśnią śpiewaną przez pielgrzymów zmierzających do Miasta Świętego. Zwyczaj pielgrzymowania do Jerozolimy po-

${ }^{11}$ Psalmen, dz. cyt., s. 37. 
dejmowany był przez Izraelitów z okazji najważniejszych świąt przypadających w ciągu roku, m.in. Święta Paschy, Namiotów czy Tygodni.

Inny od pozostałych charakter posiada psalm błagalny, będący modlitwą skierowaną do Jahwe. Tekst psalmu składa się z dwóch odmiennych pod względem charakteru cząstek. W początkowym fragmencie autor prosi o odpuszczenie win, natomiast od czwartego wersetu ma on już pewność, że modlitwa została wysłuchana. Psalm kończy się pełnym nadziei wezwaniem: „Et ipset redimet Izrael ex omnibus iniquitatibus ejus".

Nastrój w psalmach sapiencjalnych nie jest jednorodny. W grupie występują teksty radosne (Beatus vir), jak również takie, w których pierwotny optymizm zmienia się w zakończeniu w lamentacje (Domine probasti me). Wszystkie psalmy zawierają sentencje o charakterze moralizatorskim, nasuwające skojarzenia z biblijną Księgą Przysłów.

Ostatnim z wyróżnionych rodzajów psalmów jest In convertendo noszący cechy modlitwy, w której pojawiają się elementy błagalne („Converte, Domine, captivitatem nostram”) oraz zapowiedzi pocieszenia („Venientes autem venient cum exsultatione, portantes manipulos suos").

Nabożeństwo nieszporów kończyło się wykonaniem radosnej pieśni Maryi, która zapisana została na kartach Ewangelii świętego Łukasza (Ł 1, 46-55). Zgodnie z historią biblijną Maria wypowiedziała słowa hymnu w trakcie spotkania ze swoją krewną, Elżbietą. Mimo że tekst znajduje się na kartach Nowego Testamentu, jego konstrukcja wykorzystuje wcześniejsze wzory przejęte ze Starego Testamentu $^{12}$, m.in. liczne wersety z Księgi Psalmów. Umieszczenie w nabożeństwie hymnu o tak dużych związkach z tekstami psalmowymi wydaje się w pełni uzasadnione. W strukturze Magnificat występują także liczne metafory, które odnosić można do konkretnych wydarzeń z historii Izraela (np. odwołanie się do patriarchy rodu Abrahama). Konstrukcje gramatyczne interpretować można jako opis boskich ingerencji w dzieje narodu wybranego lub odczytywać jako indywidualne relacje Stwórcy z każdym człowiekiem na przestrzeni wieków. W wersecie „Suscepit Israel puerum suum recordatus misericordiae suae" (Ł 1, 54) pomoc Boga dotyczyć może narodu wybranego, jak również wszystkich wierzących. Pieśń Maryi nie jest jedynym hymnem autorstwa świętego Łukasza. Podobną formę posiada kantyk Zachariasza Nunc dimitis (Ł 1, 68), który stanowi stały element komplety.

${ }^{12} \mathrm{~W}$ Magnificat pojawiają się następujące nawiązania do innych fragmentów Starego Testamentu: 1 Sm 2, 1-10; Ps 113 (112), 5n; 1 Sm 1, 11; Ps 111 (110), 9; 103 (102), 17; 89 (88), 11; 2 Sm 22, 28; Ps 147 (146), 6; Hi 12, 19; Ps 107 (106), 9; 34 (33), 11; Iz 41, 8n; Ps 98 (97), 3; Mi 7, 20; Rodz 17, 7; 18, 18, 22, 17. Za: Pismo Święte Starego i Nowego Testamentu, Warszawa 1980, przypis 1, 46, s. 1181. 


\section{Typologia cyklów nieszpornych}

W archiwum paulinów na Jasnej Górze zachowało się siedem opracowań tekstów nieszporów powstałych do 1785 roku autorstwa różnych kompozytorów (por. tab. 3). Dzieła te z uwagi na funkcję liturgiczną podzielić można na trzy grupy: nieszpory niedzielne (Vesperae de dominica), nieszpory o Apostołach i Wyznawcach (Vesperae de apostolorum et confessore) oraz opracowania, które można było wykonać z okazji kilku uroczystości (np. określane pro toto anno).

\begin{tabular}{|c|c|c|c|}
\hline Nieszpory niedzielne & $\begin{array}{l}\text { Nieszpory } \\
\text { o Apostołach }\end{array}$ & $\begin{array}{l}\text { Nieszpory } \\
\text { o Wyznawcach }\end{array}$ & $\begin{array}{l}\text { Nieszpory przeznaczone } \\
\text { na kilka uroczystości }\end{array}$ \\
\hline $\begin{array}{l}\text { 1. Vesperae C Domini- } \\
\text { cales II- } 196 \\
\text { [de Apostolis, de Con- } \\
\text { fessore }] \\
\text { Pernecker }\end{array}$ & $\begin{array}{l}\text { 1. Vesperae C de Aposto- } \\
\text { lis II-184 } \\
\text { Neumann }\end{array}$ & $\begin{array}{l}\text { 1. Vesperae C de Confesso- } \\
\text { re III-953 } \\
\text { Neumann } \\
\text { 2. Vesperae C de Confesso- } \\
\text { re II-195 } \\
\text { Pernecker }\end{array}$ & $\begin{array}{l}\text { 1. Vesperae C III-50 } \\
\text { Brickner } \\
\text { 2. Vesperae D III-753 } \\
\text { Żebrowski } \\
\text { 3. Vesperae E III-197 } \\
\text { Neumann }^{13}\end{array}$ \\
\hline
\end{tabular}

Tabela 3. Typologia cyklów nieszpornych ${ }^{14}$

Niemal każdy z cyklów obejmuje pięć psalmów oraz Magnificat, bez antyfon, które wykonywano na sposób chorałowy. Wyjątkiem są Vesperae C Dominicales Perneckera, w których występuje sześć psalmów, dzięki czemu rozszerzeniu uległy możliwości wykonawcze. Większą liczbę psalmów, od 10 do 16, zawierają Vesperae Briknera oraz Żebrowskiego. Kompozycje te przeznaczone były do wykonania w ciągu całego roku kościelnego. Z obu dzieł utworzyć można zestaw psalmów wykonywanych w trakcie nieszporów niedzielnych, jak również uroczystości: apostołów, wyznawców, maryjnych, na pamiątkę poświęcenia kościoła oraz uroczystości Bożego Narodzenia i Bożego Ciała (por. tab. 4).

${ }^{13}$ Autorstwo cyklu Vesperae in E mylnie przypisane zostało przez Pawła Podejkę Franciszkowi Perneckerowi. Uznanie Neumanna za autora kompozycji było możliwe dzięki obecności cech stylistycznych charakterystycznych warsztatu tego twórcy. W zbiorach wawelskich występuje ponadto zbiór (sygnatura KK I 437), w którym znajduje się kompilacja 11 psalmów z Vesperae de Apostolis oraz Vesperae E (s. 23-57). W wymienionym źródle jako autor dzieła wymieniony jest Neumann.

${ }^{14}$ Podane w tabeli sygnatury cytowane są za katalogiem autorstwa Pawła Podejki: Katalog tematyczny rękopisów i druków muzycznych kapeli wokalno-instrumentalnej na Jasnej Górze, Warszawa 1992 (Studia Claromontana, 12). Opis źródeł: bibliografia, rękopisy muzyczne. 


\begin{tabular}{|c|c|c|c|c|c|c|c|c|c|}
\hline Cykl nieszporny & \multicolumn{9}{|c|}{ Zestaw psalmów } \\
\hline Vesperae de dominica & \multicolumn{9}{|c|}{$\begin{array}{l}\text { Dixit Dominus Ps } 110(109) \\
\text { Confitebor Ps } 111(110) \\
\text { Beatus vir Ps } 112(111) \\
\text { Laudate pueri Ps } 113(112) \\
\text { Laudate Dominum Ps } 117 \text { (116) } \\
\text { Magnificat }\end{array}$} \\
\hline Vesperae de apostolorum & \multicolumn{9}{|c|}{$\begin{array}{l}\text { Dixit Dominus Ps } 110 \text { (109) } \\
\text { Laudate pueri Ps } 113 \text { (112) } \\
\text { Credidi Ps } 116 \text { (115) } \\
\text { In convertendo Ps } 126 \text { (125) } \\
\text { Domine probasti me Ps } 139 \text { (138) } \\
\text { Magnificat }\end{array}$} \\
\hline Vesperae de confessore & \multicolumn{9}{|c|}{$\begin{array}{l}\text { Dixit dominus Ps } 110(109) \\
\text { Confitebor Ps } 111 \text { (110) } \\
\text { Beastus vir Ps } 112(111) \\
\text { Laudate pueri Ps } 113 \text { (112) } \\
\text { Laudate Dominum Ps } 117 \text { (116) } \\
\text { Magnificat }\end{array}$} \\
\hline \multirow[t]{17}{*}{ Vesperae } & 1. & Dixit Dominus Ps 110 (109) & $\mathrm{D}$ & A & C & M & E & ND & CC \\
\hline & 2. & Confitebor tibi Domine Ps 111 (110) & $\mathrm{D}$ & & C & & E & ND & CC \\
\hline & 3. & Beatus vir Ps 112 (111) & $\mathrm{D}$ & & C & & E & ND & \\
\hline & 4. & Laudate pueri Ps 113 (112) & $\mathrm{D}$ & A & C & M & E & & \\
\hline & 5. & In exitu Ps 114 (113) & $\mathrm{D}$ & & & & & & \\
\hline & 6. & Credidi Ps 116 (115) & & A & & & & & CC \\
\hline & 7. & Laudate Dominum Ps 117 (116) & & & C & & & & \\
\hline & 8. & Laetatus sum Ps 122 (121) & & & & M & & & \\
\hline & 9. & In convertendo Ps 126 (125) & & A & & & & & \\
\hline & 10. & Nisi Dominus Ps 127 (126) & & & & M & & & \\
\hline & 11. & Beati omnes Ps 128 (127) & & & & & & & CC \\
\hline & 12. & De profundis Ps 130 (129) & & & & & & ND & \\
\hline & 13. & Memento Domine Ps 132 (131) & & & & & & ND & \\
\hline & 14. & Confitebor Ps 138 (137) & & A & & & & & \\
\hline & 15. & Domine probasti me Ps 139 (138) & & A & & & & & \\
\hline & 16. & Lauda Jerusalem Ps 147 (146) & & & & M & E & & CC \\
\hline & 17. & Magnificat & $\mathrm{D}$ & A & C & M & $\mathrm{E}$ & ND & $\mathrm{CC}$ \\
\hline
\end{tabular}

Tabela 4. Zestawy psalmów tworzące konkretny cykl nieszporny ${ }^{15}$

${ }^{15}$ Zastosowano następujące skróty: D - Vesperae de dominica, A - Vesperae de apostolorum, C - Vesperae de confessore, M - Vesperae de Beatae Mariae Virginis, E - Vesperae de dedi- 


\section{Opracowanie muzyczne nieszporów jasnogórskich}

Napięcie dramatyczne w opracowaniach tekstów vesperae zależy od talentu kompozytora (por. Montevedri, Vesperae della Beata Vergine). Poszczególnym ogniwom nieszporów brak spójności oraz gradacji napięcia, co związane jest z różnym zestawem psalmów, determinowanym przez okoliczności wykonania. Opracowanie przybiera formę odcinkową, zbliżoną do koncertu kościelnego. Podstawą jednostką jest werset lub jego część, a główną zasadą kompozycji - zestawienia kontrastowe. Obejmują one zmiany obsady, faktury, tonacji, typu melodyki oraz rytmiki, rzadziej metrum czy tempa. Wymienione elementy ulegają licznym przeobrażeniom na odcinkach kilku lub kilkunastu taktów.

Składnia tekstu na ogół odzwierciedlona była w szacie dźwiękowej, chociaż w kompozycjach jasnogórskich niejednokrotnie zauważyć można fragmenty nieoddające struktury poetyckiej. Sytuacja taka występuje w przypadku łączenia kilku wersetów w jedną całość muzyczną bądź przez stosowanie cezur w miejscach niepokrywających się z prozodią tekstu. Zabiegiem występującym u wszystkich twórców jest częste stosowanie politekstury, polegającej na jednoczesnym zestawieniu kilku (do czterech) cząstek tekstu (przykład 1). Uzyskana w ten sposób zwartość kompozycji działa na niekorzyść walorów audytywnych - zrozumiałość tekstu jest mocno ograniczona. Wielotekstowość występuje zwłaszcza w rozbudowanych psalmach (m.in. Beatus vir, Domine probasti me), jednak długość tekstu nie zawsze stanowi kryterium rozstrzygające. Na przykład w Magnificat (Vesperae de Confessore) Perneckera mimo sporej liczby wersów kompozytor tylko w jednym miejscu nakłada na siebie dwie cząstki tekstu. Jednoczesne stosowanie kilku wersów psalmów często występuje w dziełach Żebrowskiego oraz Perneckera.

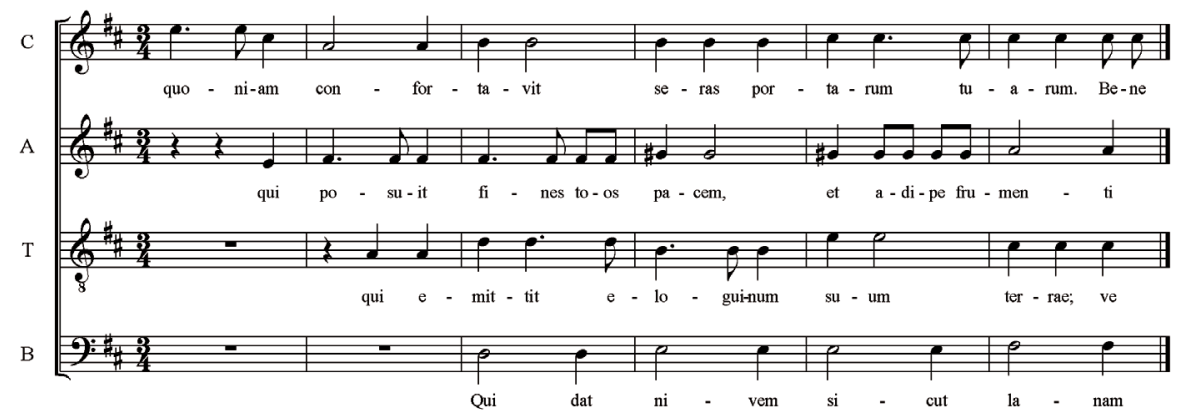

Przykład 1. Żebrowski, Vesperae D, Lauda Jerusalem t. 25-30.

catione ecclesiae, ND - Vesperae de Nativitate Domini, CC - Vesperae in Festo Corporis Christi. 


\section{Obsada}

W większości utworów zachowana jest stała obsada wokalno-instrumentalna. Prawie w każdym przypadku jest to czterogłos wokalny (canto, alto, tenore, basso), który we fragmentach dzieła lub jego odcinkach zredukowany został do faktury solowej bądź duetu. Jedynie Vesperae $C$ Briknera przeznaczone zostały na dwa głosy wokalne: sopran i bas.

Stały zestaw akompaniujący stanowi Kirchentrio - dwoje skrzypiec i basso continuo, który wzbogacono dwoma clarinii w ogniwach tworzących ramy cyklu ( $D i$ xit Dominus, Magnificat). Clarinii nie występują także w Vesperae E Neumanna, istnieje jednak duże prawdopodobieństwo, że głosy te nie zachowały się do chwili obecnej ${ }^{16}$. Wewnątrz cyklu trąbki pojawiają się sporadycznie. Jedynym przykładem ich występowania jest psalm Lauda Jerusalem Żebrowskiego (Vesperae D).

\section{Roclzaje faktury $\mathrm{i}$ charakterystyka partii instrumentalnych}

We wszystkich kompozycjach zestawianie krótkie odcinków, wersetów lub ich części polega na operowaniu kontrastującymi rodzajami faktury. W opracowaniach najczęściej przeciwstawiane są fragmenty realizowane przez cały zespół tutti odcinkom chóralnym lub solowym z akompaniamentem organów. Redukcja obsady wokalno-instrumentalnej związana jest często ze zmianą techniki kompozytorskiej. W takich przypadkach kontrast osiągany jest przez zestawienie ustępów homogenicznych z poligenicznymi albo fragmentów homorytmicznych z polifonicznymi.

a) Faktura ustępów chóralnych oraz małogłosowych

W opracowaniach tekstów nieszpornych przeważają czterogłosowe partie chóralne. Budowa odcinków tego typu wykazuje różnorodność rozwiązań formalnych. We fragmentach homorytmicznych głosy prowadzone są akordowo lub z niewielkimi odstępstwami (przykład 2). Linia melodyczna wykorzystuje repetowane dźwięki, często w tych samych wartościach rytmicznych, bez większych skoków interwałowych. Konsekwencją takiego rozwiązania jest deklamacyjny charakter danego fragmentu kompozycji. Faktura homorytmiczna występuje u wszystkich twórców, zwłaszcza w dziełach Perneckera. Oba cykle nieszporne

\footnotetext{
${ }^{16}$ Wskazuje na to architektonika pozostałych nieszporów Neumanna, w których widoczne są stałe koncepcje formy, m.in. występowanie clarinii w częściach skrajnych cyklu.
} 
tego kompozytora wyróżnia duża liczba odcinków homorytmicznych ze statyczną partią chóru, w wygodnych dla śpiewaków rejestrach.

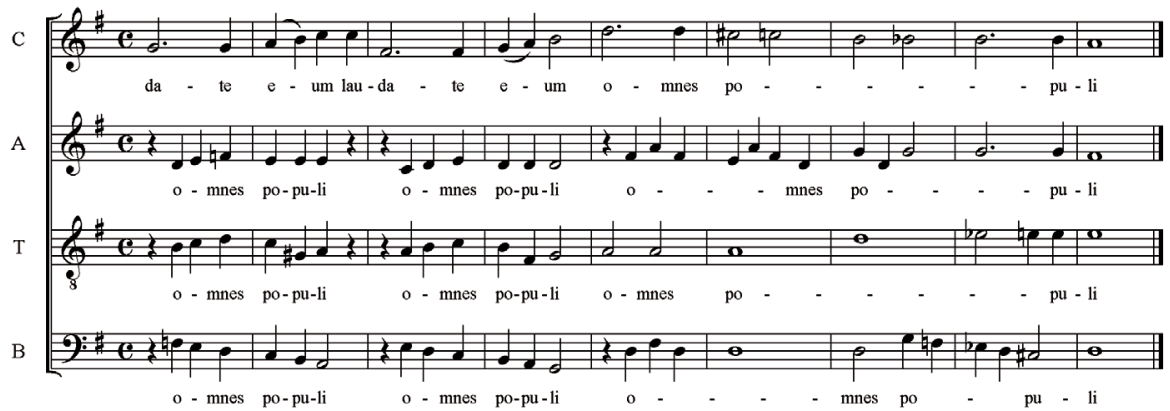

Przykład 2. Pernecker, Vesperae Dominicales, Laudate Dominum, t. 1-9.

Innym rodzajem faktury są ustępy poligeniczne, w których wyróżnić można od dwóch do czterech planów (przykład 3). W takich przypadkach jeden lub kilka głosów prowadzone są w jednakowych wartościach (pary głosów), podczas gdy pozostałe dialogują ze sobą lub tworzą grupę przeciwstawną. Melodyka owych fragmentów posiada znacznie szerszy ambitus oraz większe zróżnicowanie w zakresie wykorzystanych odległości interwałowych. Częste stosowanie dwóch planów, sopran-alt oraz tenor-bas, występuje w dziełach Żebrowskiego. Twórca chętnie posługiwał się parami głosów, które wprowadzał kolejno lub zestawiał jednocześnie. Skłonność do operowania fakturą tego typu zaobserwować można także w kompozycjach Neumanna.

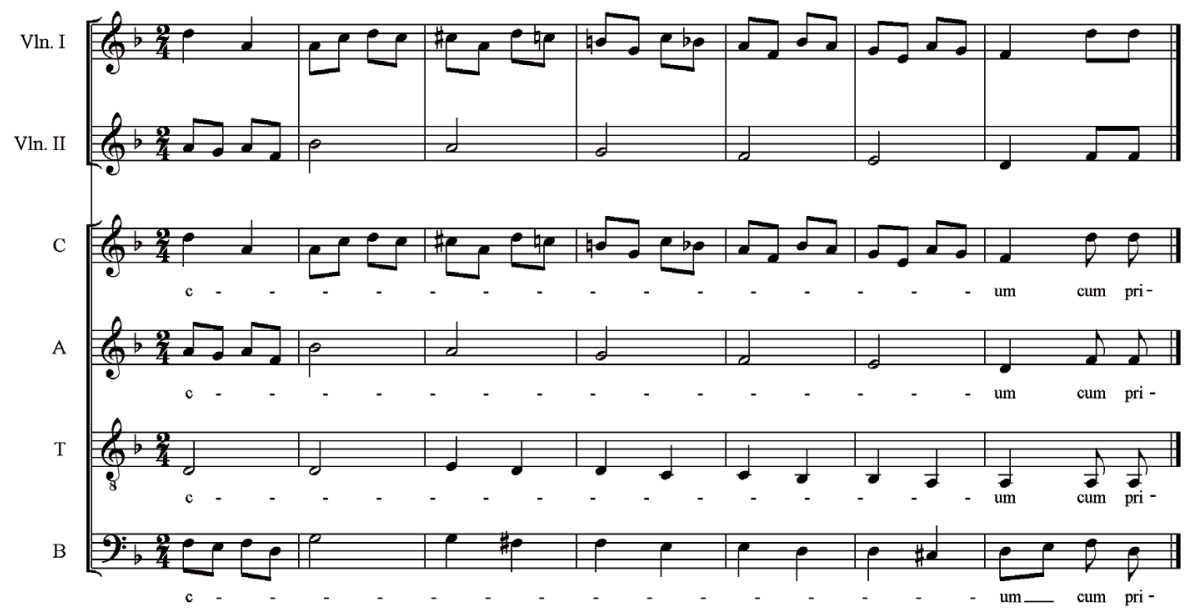

Przykład 3. Pernecker, Vesperae de Confessore, Laudate pueri, t. 37-43. 
Obok pełnego brzmienia chóru w analizowanym repertuarze występują fragmenty małogłosowe. Zestawienie brzmienia czterogłosu ze składem kameralnym służy uwypukleniu walorów kolorystycznych dzieła. Najczęściej zabieg ten polega na prezentowaniu grupy głosów zespołu wokalnego (przykład 4) lub wyróżnieniu jednej partii solowej (przykład 5).
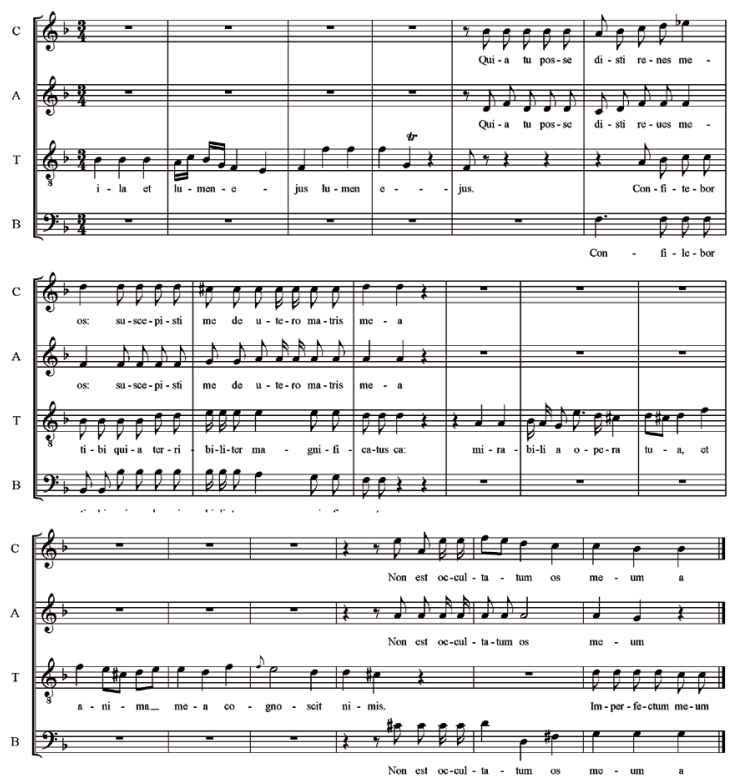

Przykład 4. Neumann, Vesperae de Apostolis, Domine probasti, t. 72-89.

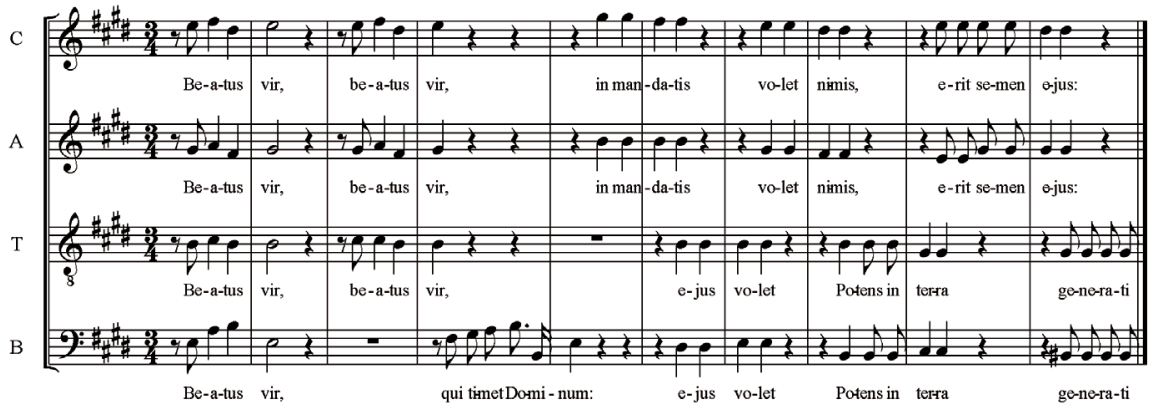

Przykład 5. Żebrowski, Vesperae D, Beatus vir, t. 1-10. 
Zestawienie typu tutti-solo występuje u wszystkich twórców (z wyjątkiem Briknera), jednak różni się częstością występowania. O ile w kompozycjach Żebrowskiego i Neumanna liczba fragmentów tego typu jest duża, w dziełach Perneckera zdecydowanie mniejsza. We wszystkich cyklach partie solowe powierzane są każdemu z głosów, jednak zauważyć można predylekcję do eksponowania partii sopranu lub basu. W kompozycjach Perneckera, Neumanna i Żebrowskiego kilkutaktowe ustępy małogłosowe stanowią rodzaj wprowadzenia lub zakończenia większych odcinków chóralnych. Rozwiązanie tego typu może być nawiązaniem do intonacji występującej w tradycji chorałowej.

Oprócz faktury solowej w cyklach nieszpornych często występują duety, rzadziej tercety. Z konfiguracji dwugłosowych najczęściej spotykanym rozwiązaniem jest zestawienie sopranu i altu oraz tenoru i basu, sporadycznie głosów wewnętrznych.

b) Arie i duety

Opracowanie całych psalmów lub wersetów jako ustępów aryjnych jest zjawiskiem rzadkim, bowiem ogranicza się do łącznej liczby pięciu utworów w cyklach Żebrowskiego i Briknera (por. tab. 5). Arie wykazują różnorodność architektoniki wewnętrznej, odmiennej u obydwu twórców.

\begin{tabular}{|l|l|l|l|l|l|}
\hline M. J. Żebrowski & Ebsada & Forma & Część vesperae & Obsada & forma \\
\hline Częśc vesperae & Obsad & A & & & \\
\hline 1. Credidi & S, 1+2 vlno, bc & ABA1C & Laudate pueri & S, 1+2 vlno, bc & wieloodcinkowa \\
\hline $\begin{array}{l}\text { 2. Quia respexit } \\
\text { (Magnificat) }\end{array}$ & S, 1+2 vlno, bc & AA1 & 2. Nisi Dominus & B, 1+2 vlno, bc & wieloodcinkowa \\
\hline $\begin{array}{l}\text { 3. Deposuit poten- } \\
\text { tes (Magnificat) }\end{array}$ & B, bc & ABA1 & & & \\
\hline
\end{tabular}

Tabela 5. Ustępy aryjne w cyklach nieszpornych.

W przypadku utworów Żebrowskiego tekst biblijny opracowany został w postaci arii dwu- $\left(\mathrm{AA}_{1}\right)$ i czteroczęściowej $\left(\mathrm{ABA}_{1} \mathrm{C}\right) \mathrm{z}$ zachowaniem kontrastu tonalnego między ogniwami. Części oddzielone są instrumentalnymi ritornelami, które pełnią funkcje m.in. modulacji do kolejnych segmentów utworu. Jedynie w Deposuit potentes brak odcinków instrumentalnych, kolejne ogniwa łączone są bezpośrednio. Architektonikę arii można wyrazić schematem: 


$$
\begin{aligned}
& \mathrm{r}-\mathrm{A}-\mathrm{r}-\mathrm{B} / \mathrm{A}_{1}{ }^{17 /}-\mathrm{r}-\mathrm{A}_{1}-\mathrm{r}-\mathrm{C} \\
& \mathrm{T} \rightarrow \mathrm{T} / \mathrm{D} \rightarrow \mathrm{D} \rightarrow \mathrm{D} /{ }_{\mathrm{o}} \mathrm{T}^{\mathrm{III}} \rightarrow{ }^{\circ} \mathrm{T}_{\mathrm{III}} \rightarrow \mathrm{T} \quad \rightarrow \quad \mathrm{D} / \mathrm{T}^{18} \\
& \mathrm{~T} \rightarrow \mathrm{T} / \mathrm{D} \rightarrow \mathrm{D} \rightarrow \mathrm{D} / \mathrm{T} \rightarrow \mathrm{T}^{19} \\
& \mathrm{~T}^{\mathrm{o}} \rightarrow \mathrm{T}^{\mathrm{o}} \rightarrow \text { (modulacja) } \rightarrow \mathrm{D} \quad \rightarrow \quad \mathrm{S}^{\circ} / \mathrm{T}^{\mathrm{o}} \rightarrow \quad \rightarrow \quad \mathrm{T}^{\mathrm{b} 20}
\end{aligned}
$$

Inna koncepcja formy występuje w ariach Briknera. Kolejne wersety psalmu tworzą wieloodcinkową całość muzyczną, której ogniwa także oddzielają instrumentalne ritornele. Fragmenty te pełnią funkcję modulacji do kolejnych cząstek utworu, jak również integrują całość dzięki występującym w nich stałym figurom melodyczno-rytmicznym

W Vesperae D Żebrowskiego dwa psalmy opracowane zostały w formie duetów. Kompozycje te przyjmują architektonikę czteroczęściową o różnym następstwie ogniw $\left(\mathrm{ABA}_{1} \mathrm{C}\right.$ oraz $\mathrm{ABCA}_{1}$ ) oddzielonych ritornelami. Budowa duetów wykazuje duże podobieństwo do arii, jednak z pominięciem ostatniego fragmentu instrumentalnego.

$$
\begin{aligned}
& \mathrm{r}-\mathrm{A}-\mathrm{r}-\mathrm{B}-\mathrm{r}-\mathrm{A}_{1}{ }^{21} / \mathrm{C}-\mathrm{C} / \mathrm{A}_{1} \\
& \mathrm{~T} \rightarrow \mathrm{T} / \mathrm{D} \rightarrow \mathrm{D} \quad \rightarrow \quad \mathrm{D} /{ }^{\circ} \mathrm{T}_{\mathrm{III}} \rightarrow{ }^{\circ} \mathrm{T}_{\mathrm{III}} \rightarrow \mathrm{D} \quad \rightarrow \quad \mathrm{D} / \mathrm{T}^{22} \\
& \mathrm{~T}^{\mathrm{o}} \rightarrow \mathrm{T}^{\mathrm{o}} / \mathrm{S}^{\circ} \rightarrow \mathrm{S}^{\circ} \rightarrow \mathrm{S}^{\circ} \mathrm{T}^{\mathrm{o}} \rightarrow \mathrm{S}^{\circ} \quad \mathrm{D} \quad \rightarrow \quad \mathrm{To}^{23}
\end{aligned}
$$

c) Partie instrumentalne

Funkcja instrumentów najczęściej zależy od typu faktury występującego w danym fragmencie utworu. W odcinkach tutti partie instrumentalne przeważnie dublują głosy wokalne (por. przykład 3). Skrzypce, ewentualnie clarinii, zdwajają

\footnotetext{
${ }^{17}$ Oznaczenie A1 dotyczy drugich części arii In convertendo oraz Quia respexit Żebrowskiego, które nawiązują do pierwszego ogniwa A.

${ }^{18}$ In convertendo.

${ }^{19}$ Quia respexit.

${ }^{20}$ Deposuit potentes.

${ }^{21}$ Trzecie ogniwo kompozycji Laetatus sum oraz Nisi Dominus jest albo nawiązaniem do pierwszego (A1), albo posiada nowy materiał muzyczny (C).

${ }^{22}$ Laetatus sum.

${ }^{23}$ Nisi Dominus.
} 

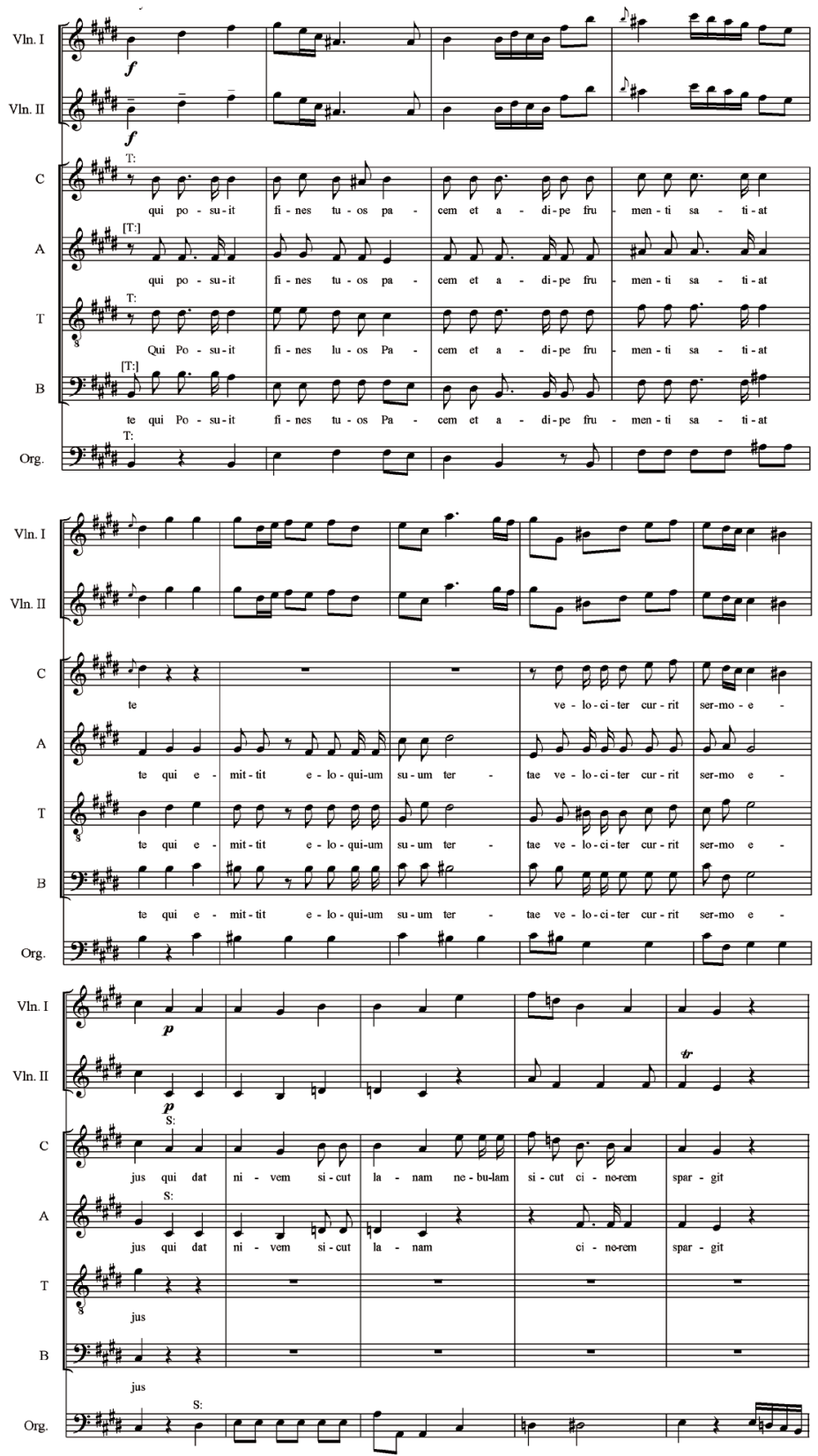

Przykład 6. Neumann, Vesperae E, Lauda Jerusalem, t. 14-27. 


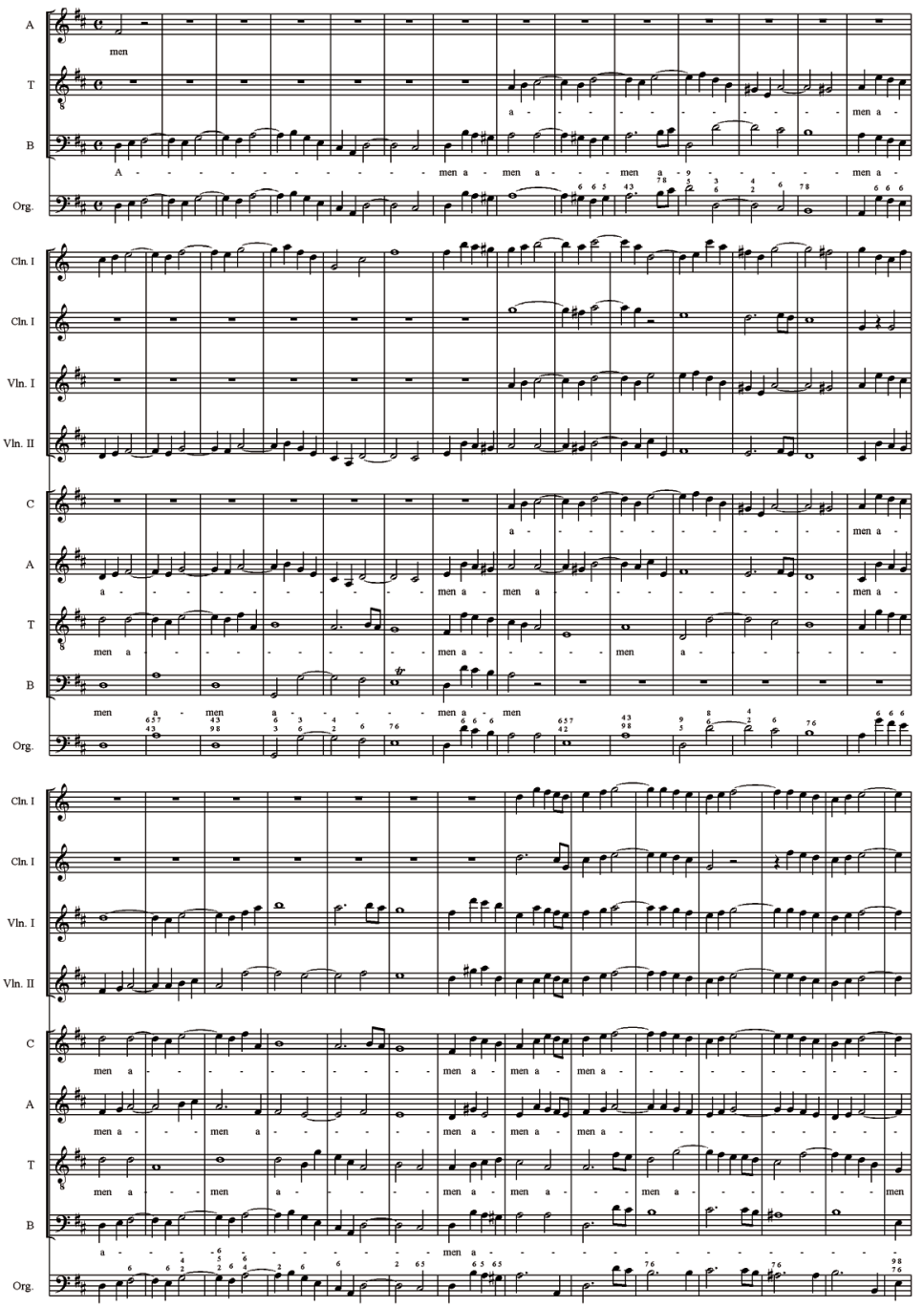

Przykład 7. Żebrowski, Vesperae D, Dixit Dominus, t. 148-189.

głosy wyższe, natomiast basso continuo dwoi partię basu wokalnego. W dziełach Perneckera niezależność instrumentów smyczkowych jest mocno ograniczona. Oprócz wspomagania głosów wokalnych skrzypce wykonują niewielkich rozmiarów ozdobniki w toku i zakończeniu fraz, wzbogacając kadencje chóru. Instrumenty te wykorzystane są także w funkcji kolorystycznej - wypełniają brzmienie tutti oraz potęgują efekty dynamiczne. Samodzielne partie pojawiają się sporadycznie, przeważnie jako figuracyjny akompaniament z silnie eksponowanym 

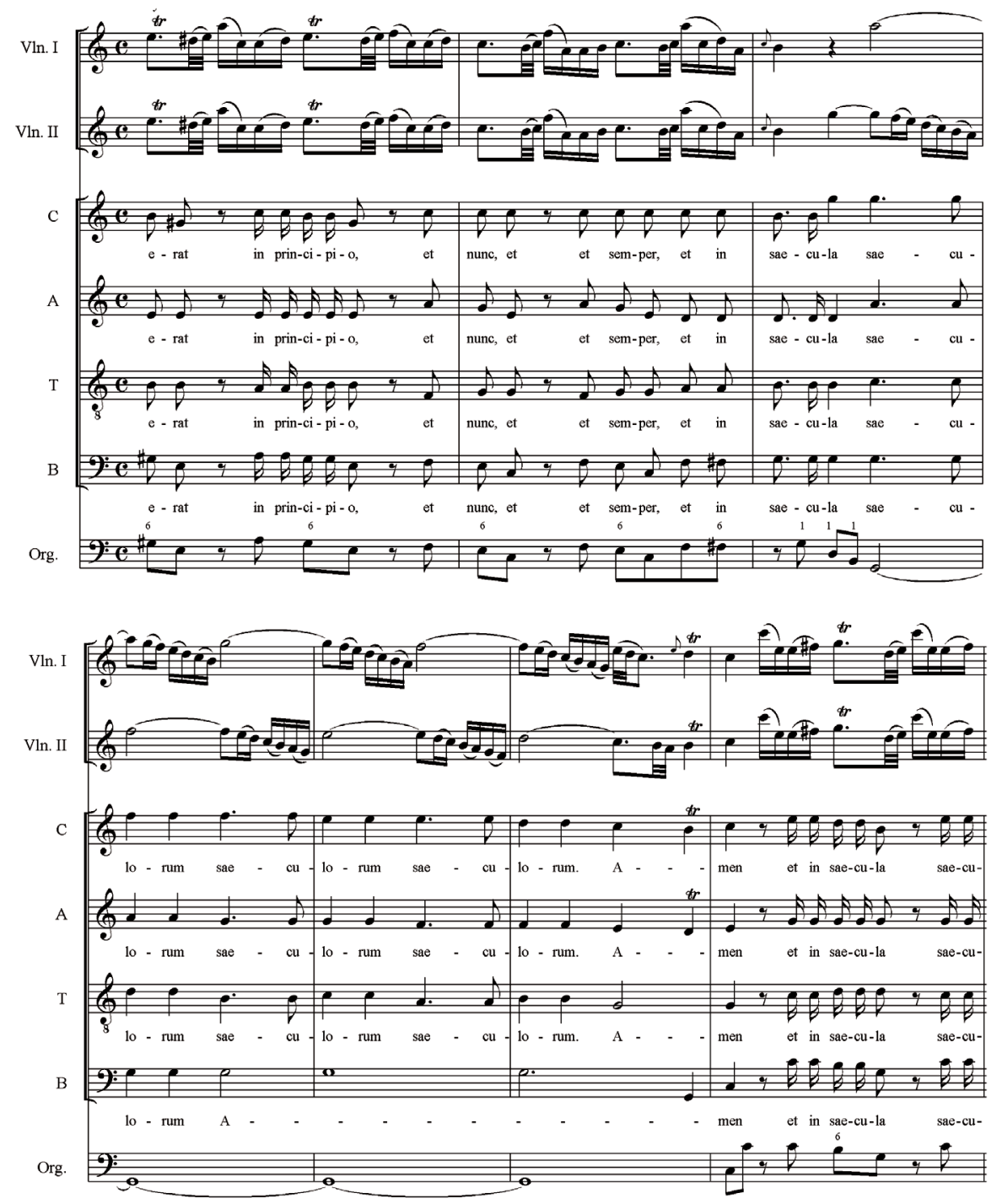

Przykład 8. Żebrowski, Vesperae D, Domine probasti, t. 61-67.

elementem wirtuozowskim. Ritornele instrumentalne są elementem charakterystycznym kompozycji Briknera. Oprócz funkcji wstępu i modulacji w ariach odcinki te dzielą poszczególne wersety psalmów w duetach.

Bardziej samodzielne partie instrumentalne w odcinkach tutti występują w cyklach Żebrowskiego i Neumanna (przykład 6). Zdwajanie głosów wokalnych występuje 
zwłaszcza w fakturze polifonicznej (przykład 7). Natomiast homorytmicznym fragmentom chóralnym towarzyszy akompaniament z niezależnymi partiami instrumentów (por. przykład 6). Kolorystyczne efekty skrzypiec w kompozycjach Żebrowskiego często polegają na szybkich przebiegach po stopniach gamy lub trójdźwięku (przykład 8).

W ustępach aryjnych oraz duetach widoczna jest większa niezależność w stosunku do partii wokalnych (np. Credidi, Vesperae D Żebrowskiego). We fragmentach tego typu często wykorzystane zostały elementy techniki koncertującej polegające na wymianie motywicznej między głosami.

Partie clarini pełnią głównie funkcje dynamiczną, uwypuklając walory kolorystyczne dzieła. Zazwyczaj głosy trąbek zdwajają w unisono partie pierwszych i drugich skrzypiec, w żadnej kompozycji nie wykonują odcinków solowych. W innych fragmentach instrumenty dęte występują w funkcji rytmicznej, podkreślając miarę taktu (przykład 9).

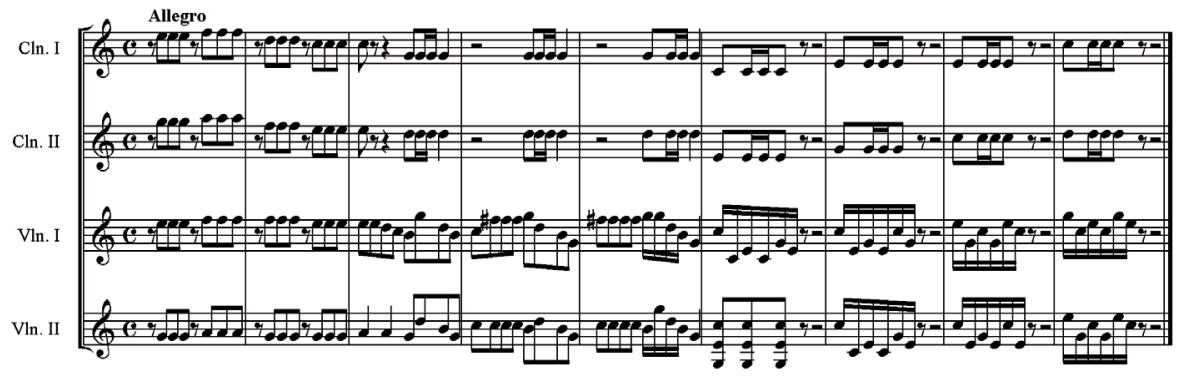

Przykład 9. Pernecker, Vesperae de Confessore, Magnificat, t. 1-9.

W cyklach nieszpornych występuje kilka typów kształtowania partii basso pro organo. Pojawiają się fragmenty basso seguente (In exitu, Pernecker), jak również akompaniamentu będącego wypełnieniem harmonicznym. We wszystkich utworach głos ten został ocyfrowany, zaś rodzaj oznaczeń nie wykracza poza normy przyjęte w XVIII-wiecznej sztuce kompozycji.

\section{Dobór tonacji}

Tonacje ogniw tworzących ramy nieszporów są w miarę jednorodne. W przeważającej części twórcy wykorzystali materiał skali C, jedynie w dwóch przypadkach pojawia się D oraz E. Taki dobór tonacji podyktowany został względami praktycznymi i wiąże się z użyciem clarini w skrajnych częściach cyklów. Krąg tonalny ogniw wewnętrznych jest o wiele bardziej zróżnicowany. Zwracają uwagę podobieństwa w opracowaniach tych samych tekstów psalmów przez różnych 
twórców (por. tab. 6), które polegają na wykorzystaniu tej samej tonacji, metrum bądź faktury.

\begin{tabular}{|c|c|c|c|c|c|c|c|}
\hline Psalm & $\dot{\mathbf{Z}}$ & NI & NII & NIII & PI & PII & B \\
\hline \multirow{2}{*}{$\begin{array}{l}\text { Dixit Dominus } \\
\text { Ps } 110(109)\end{array}$} & $\mathrm{D}, \mathrm{C}$ & $\mathrm{C}, \mathrm{C}$ & $\mathrm{C}, \mathrm{C}$ & E, C & C, $3 / 4$ & C, C & C, C \\
\hline & Tutti & Tutti & Tutti & Tutti & Tutti & Tutti & $S+B$ \\
\hline \multirow{2}{*}{$\begin{array}{l}\text { Confitebor } \\
\text { Ps } 111 \text { (110) }\end{array}$} & e, C & E, $3 / 4$ & & e, C & F, $2 / 4$ & $\mathrm{G}, 2 / 4$ & Es, C \\
\hline & tutti & Tutti/solo & & tutti & Tutti/solo & Tutti/solo & $S+B$ \\
\hline \multirow{2}{*}{$\begin{array}{l}\text { Beatus vir } \\
\text { Ps } 112(111)\end{array}$} & E, $3 / 4$ & E, C & & E, $3 / 4$ & $\mathrm{D}, 3 / 4$ & A, $3 / 8$ & $a, 3 / 4$ \\
\hline & Tutti/solo & Tutti/solo & & Tutti/solo & Tutti/solo & Tutti & $S+B$ \\
\hline \multirow{2}{*}{$\begin{array}{l}\text { Laudate pueri } \\
\text { Ps } 113 \text { (112) }\end{array}$} & A, $2 / 4$ & $\mathrm{G}, \mathrm{C}$ & & A, $2 / 4$ & $G, 2 / 4$ & F, $2 / 4$ & C, C \\
\hline & Tutti/solo & Tutti, solo & & Tutti/solo & Tutti & Tutti & $S+B$ \\
\hline \multirow{2}{*}{$\begin{array}{l}\text { Credidi } \\
\text { Ps } 116(115)\end{array}$} & $B, 2 / 4$ & & G, C & & & & $\mathrm{D}, 3 / 4$ \\
\hline & & & & & & & $S+B$ \\
\hline \multirow{2}{*}{$\begin{array}{l}\text { Laudate Domi- } \\
\text { num } \\
\text { Ps } 117 \text { (116) }\end{array}$} & $\mathrm{G}, \mathrm{C}$ & $\mathrm{C}, \mathrm{C}$ & & $\mathrm{G}, \mathrm{C}$ & e, $\mathbb{C}$ & d, $3 / 4$ & $\mathrm{D}, \mathrm{C}$ \\
\hline & Tutti & Tutti/solo & & Tutti & tutti & tutti & $\mathrm{S}+\mathrm{B}$ \\
\hline \multirow{2}{*}{$\begin{array}{l}\text { Laetatus sum } \\
\text { Ps } 122(121)\end{array}$} & F, $2 / 4$ & & & F, $2 / 4$ & & & F, C \\
\hline & $\mathrm{S}+\mathrm{A}$ & & & $\mathrm{S}+\mathrm{A}$ & & & $\mathrm{S}+\mathrm{B}$ \\
\hline \multirow{2}{*}{$\begin{array}{l}\text { In convertendo } \\
\text { Ps } 126(125)\end{array}$} & $\mathrm{d}, 3 / 4$ & & $\mathrm{D}, \mathrm{C}$ & & & & h, C \\
\hline & $\mathrm{S}+\mathrm{A}+\mathrm{B}$ & & $\mathrm{A} /$ tutti & & & & $\mathrm{S}+\mathrm{B}$ \\
\hline \multirow{2}{*}{$\begin{array}{l}\text { Nisi Dominus } \\
\text { Ps } 127(126)\end{array}$} & $\mathrm{g}, \mathbb{C}$ & & & $\mathrm{g}, \mathbb{C}$ & & & $\mathrm{d}, \mathrm{C}$ \\
\hline & $\mathrm{T}+\mathrm{B}$ & & & $\mathrm{T}+\mathrm{B}$ & & & B \\
\hline \multirow{2}{*}{$\begin{array}{l}\text { Domine proba- } \\
\text { sti me } \\
\text { Ps } 139 \text { (138) }\end{array}$} & $\mathrm{C}, \mathbb{C}$ & & $\mathrm{F}, 3 / 4$ & & & & A, C \\
\hline & Tutti/solo & & $\begin{array}{l}\text { Tutti/ } \\
\text { solo }\end{array}$ & & & & $S+B$ \\
\hline \multirow{2}{*}{$\begin{array}{l}\text { Lauda Jerusalem } \\
\text { Ps } 147 \text { (146) }\end{array}$} & $\mathrm{D}, 3 / 4$ & & & $\mathrm{D}, 3 / 4$ & & & \\
\hline & Tutti/solo & & & Tutti/solo & & & \\
\hline \multirow[t]{3}{*}{ Magnificat } & $\mathrm{D}, 3 / 4$ & $\mathrm{C}, \mathrm{C}$ & $\mathrm{C}, \mathrm{C}$ & $\mathrm{E}, \mathrm{C}$ & $\mathrm{C}, \mathrm{C}$ & $\mathrm{C}, \mathrm{C}$ & $\mathrm{C}$ \\
\hline & Tutti & $C, 3 / 4$ & Tutti & Tutti & $\mathrm{C}, 3 / 8$ & $\mathrm{C}, 3 / 8$ & $S+B$ \\
\hline & & tutti & & & Tutti & Tutti & \\
\hline
\end{tabular}

Tabela 6. Teksty psalmów opracowane przez różnych kompozytorów jasnogórskich ${ }^{24}$

${ }^{24}$ Zastosowane skróty: Ż - Vesperae D, Żebrowski; NI - Vesperae de Apostolis, Neumann; NII - Vesperae de Confessore, Neumann; NIII - Vesperae E, Neumann; PI - Vesperae Dominicales, Pernecker; PII - Vesperae de Confessore, Pernecker; B - Vesperae C, Brikner. Duże litery oznaczają tonacje durowe, małe molowe. 


\section{Muzyczna ilustracja tekstów nieszpornych}

Szata dźwiękowa tekstów nieszpornych ukształtowana została z wykorzystaniem prawideł retorycznych. Afekty zawarte w tekstach psalmów wyrażone zostały w opracowaniu za pomocą figur dźwiękowych, rozwiązań fakturalnych, zmian faktury czy kontrastu rejestrów. Wymienione elementy występują w różnym nasileniu w dziełach czterech kompozytorów jasnogórskich, którzy w odmienny sposób łączą tradycję barokowej kompozycji z estetyką zapowiadającą epokę klasycyzmu.

\section{a) Afekty radosne}

W analizowanym repertuarze interpretacja słowa wyrażona została najczęściej w melodyce partii wokalnych i instrumentalnych, czego konsekwencją są odpowiednie figury anabasis oraz catabasis. Pierwsza $\mathrm{z}$ wymienionych obrazuje ruch w kierunku wznoszącym: „Si ascendero in coelum” (przykład 10), „excelsus super omnes" (Neumann Vesperae de Confessore, Laudate pueri, t. 8-9), wychwalanie Boga Laudate pueri (Żebrowski Vesperae D, t. 1-6) oraz radość wewnętrzną „Et exultavit spiritus" (przykład 11). Opadający kierunek linii melodycznej - catabasis - ilustrować może światłość pojawiającą się w mrokach: „exortum est in tenebris lumen rectis" (przykład 12). Niejednokrotnie dwie figury występują w toku kompozycji obok siebie, ilustrując odległość ziemi i nieba: „qui in altis habitat et humilia respicit in coelo et in terra” (przykład 13) oraz czynność wstępowania i zstępowania „si ascendero in coelum / si descendero in infernum” (przykład 14).

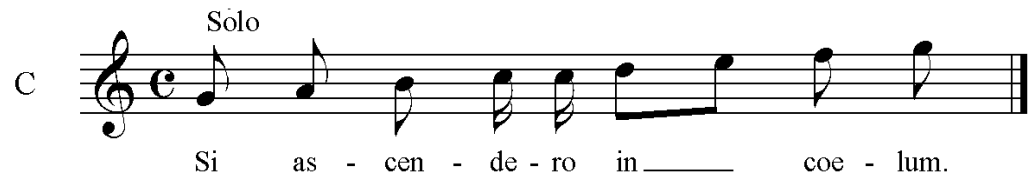

Przykład 10. Żebrowski, Vesperae D, Domine Probasti, t. 18.

Przekroczenie skali głosu, hyperbole, jest muzyczną ilustracją poskromienia żądzy człowieka - „implevit desiderium suum” (przykład 15), a także wzywaniem Jego pomocy, „invocabo” (przykład 16). Wieczne królowanie Najwyższego oddane zostało za pomocą długiej wartości rytmicznej, tenuty „in saeculum saeculi” (przykład 17). Aposiopesis, pauza we wszystkich głosach jest stosunkowo rzadko spotykaną figurą. Występuje m.in. nad słowami „non paenitebit” (przykład 18).

Kompozytorzy obok interpretacji, które można zdefiniować w kategoriach figur, posługiwali się innymi środkami. Jednym z najczęstszych sposobów uwypuklenia verba affectorum są melizmaty. Rozbudowane konstrukcje tego typu 
$\mathrm{C}$

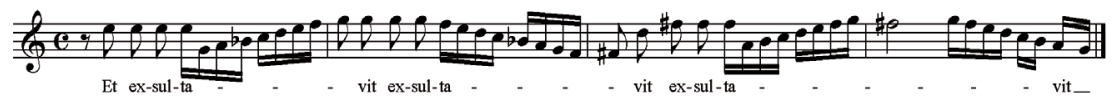

Przykład 11. Neumann, Vesperae de Apostolis, Magnificat, t. 3-6.

$\mathrm{B}$

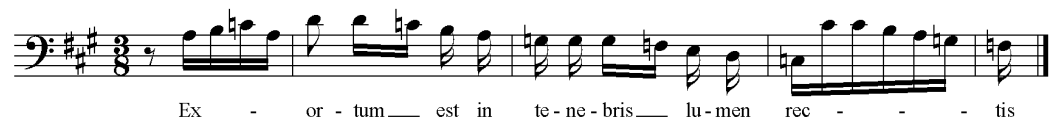

Przykład 12. Pernecker, Vesperae de Confessore, Beatus vir, t. 19-22.

B

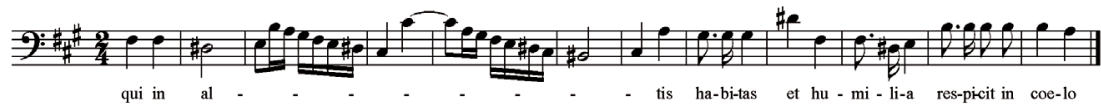

Przykład 13. Żebrowski, Vesperae D, Laudate pueri, t. 36-47.

$\mathrm{T}$

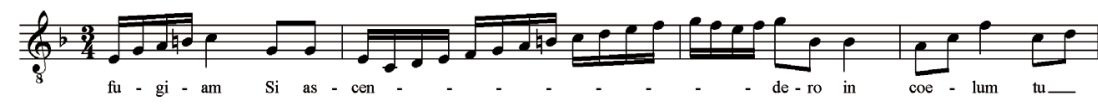

$\mathrm{T}$

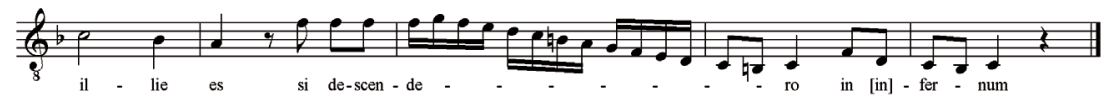

Przykład 14. Neumann, Vesperae de Apostoli, Domine probasti, t. 25-33.

$\mathrm{I}$

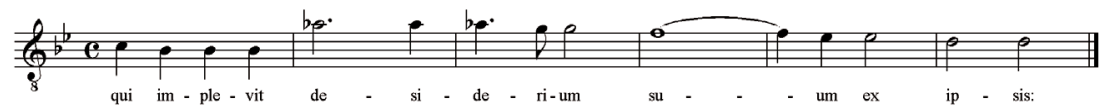

Przykład 15. Żebrowski, Vesperae D, Nisi Dominus, t. 64-66.

występują m.in. nad słowami: „nomen Domini” (przykład 19), „exultatione” (przykład 20), „gloria eius” (przykład 21). Występowanie melizmatów w funkcji uwydatniającej istotne słowa jest charakterystyczne dla wszystkich twórców 
B

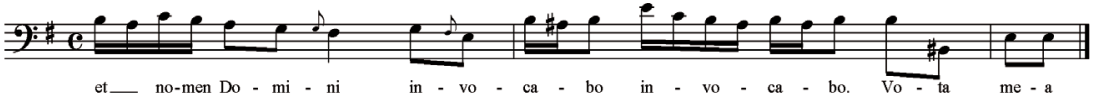

Przykład 16. Neumann, Vesperae de Confessore, Credidi, t. 38-39.

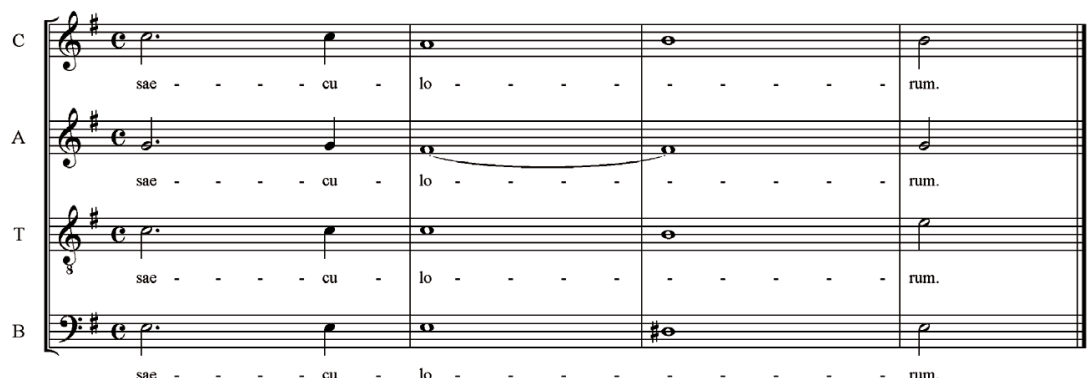

Przykład 17. Żebrowski, Vesperae D, Confitebor, t. 100-103.

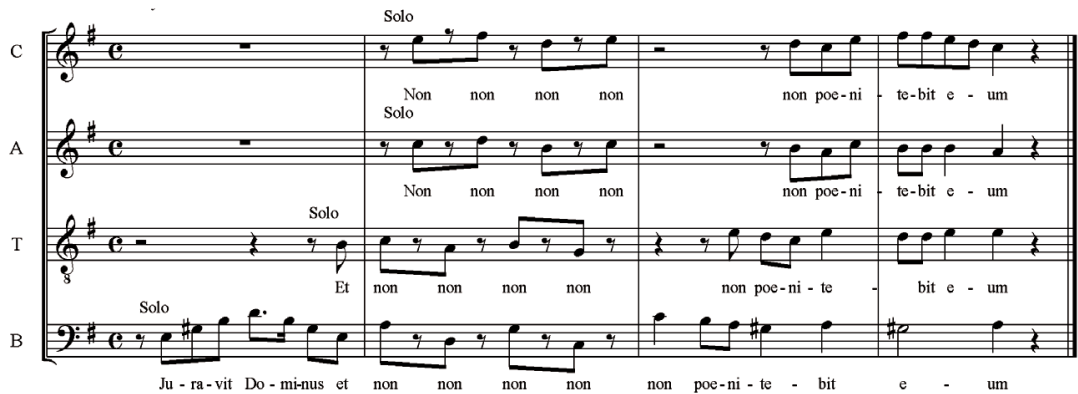

Przykład 18. Neumann, Vesperae de Apostolis, Dixit Dominus, t. 24-27.

$\mathrm{C}$

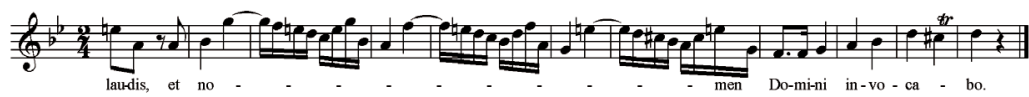

Przykład 19. Żebrowski Vesperae D, Credidi, t. 81-91.

z wyjątkiem Briknera - u niego konstrukcje melizmatyczne nie są zabiegiem retorycznym.

Zestawienie kontrastujących rejestrów jest często stosowanym środkiem ilustrującym. W ten sposób zaznaczono ciągłość pokoleń Izraela: „a pro genie in pro- 


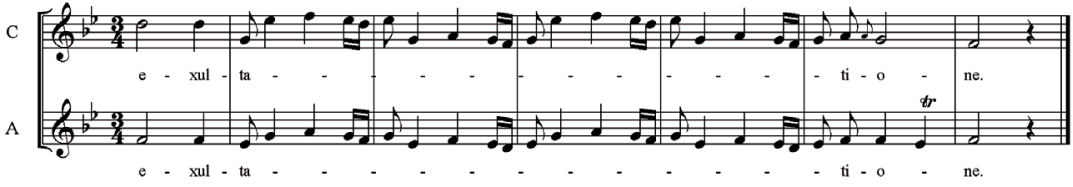

Przykład 20. Żebrowski, Vesperae D, In Convertendo, t. 21-27.

genites” (przykład 22), sąd i przykazania Boże: „veritas et judicium fidelia omnia mandata ejus” (przykład 23), światłość oraz ciemność: „conculcabunt / illuminatio” (przykład 24). Rejestr wysoki ilustruje słowa związane z jutrzenką: „ante luciferum” (przykład 25) oraz niebiosami: „in coelo” (przykład 26). Niska skala głosu obrazuje poniżenie i ubóstwo: „dispersit debit pauperibus” (przykład 27), a także minione pokolenia Izraela: „sicut locutus est ad patres nostros Abraham” (przykład 28).

Uwypuklaniu semantyki tekstu niejednokrotnie służą zmiany faktury. W obsadzie tutti opracowano słowa mówiące o wielości: „omnes gentes” (przykład 29), podkreślające powagę prawdy: „veritas domini” (przykład 30). Powiększona obsada wokalna uwydatnia potęgę Stwórcy: „cornu ejus exaltabitur in gloria” (np. tercet głosów wyższych, przykład 31).

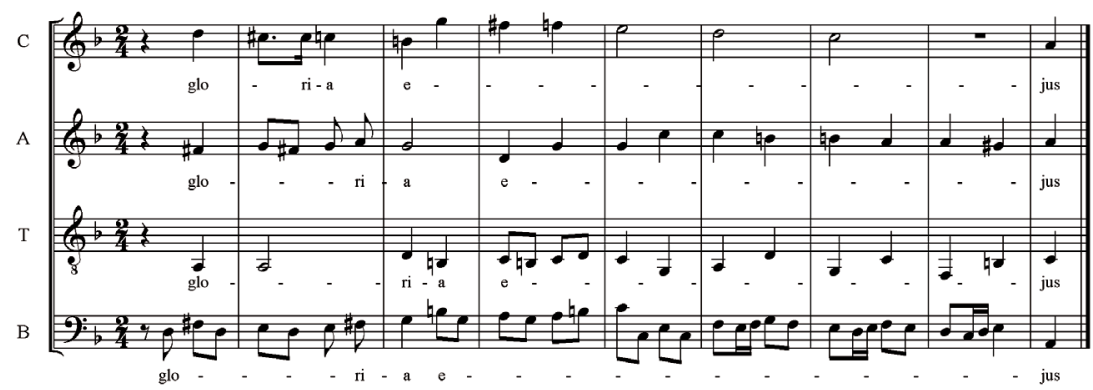

Przykład 21. Pernecker, Vesperae de Confessore, Laudate pueri, 30-38.

C

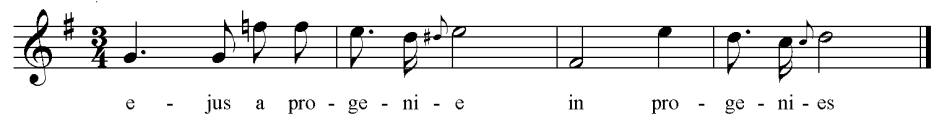

Przykład 22. Żebrowski, Vesperae D, Magnificat, t. 101-104. 
Uroczysty nastrój wyrażony został przy użyciu rytmów punktowanych. Charakter fanfarowy ma początek psalmu: „Lauda Jerusalem” (podkreślony przez partie instrumentalne, przykład 32), oraz: „Dixit Dominus” (przykład 33). Podobną

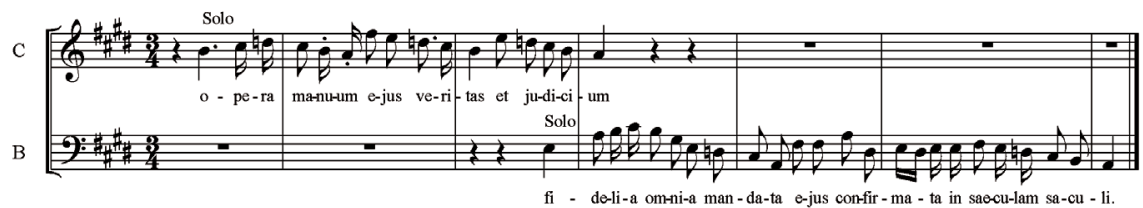

Przykład 23. Neumann, Vesperae de Confessore, Confitebor, t. 19-25.

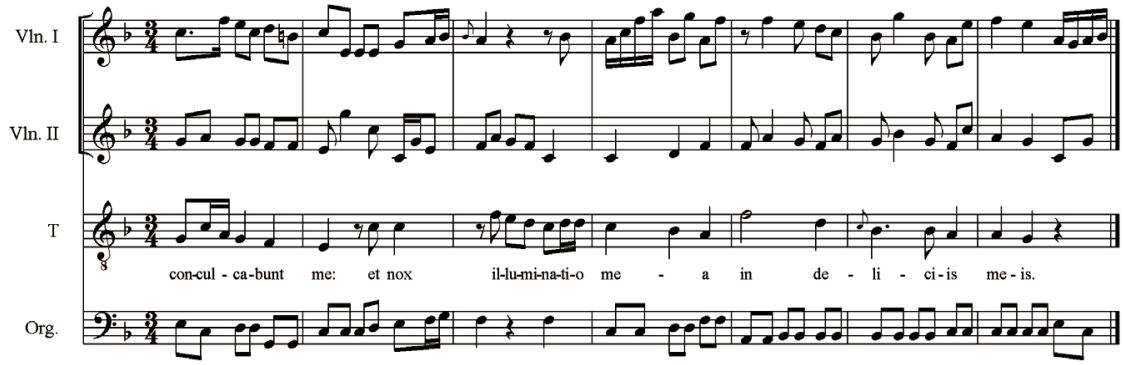

Przykład 24. Neumann, Vesperae de Apostolis, Domine probasti, t. 56-58.

$\mathrm{C}$

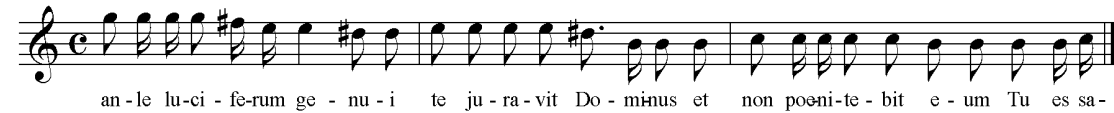

Przykład 25. Neumann, Vesperae de Confessores, Dixit Dominus, t. 9-11.

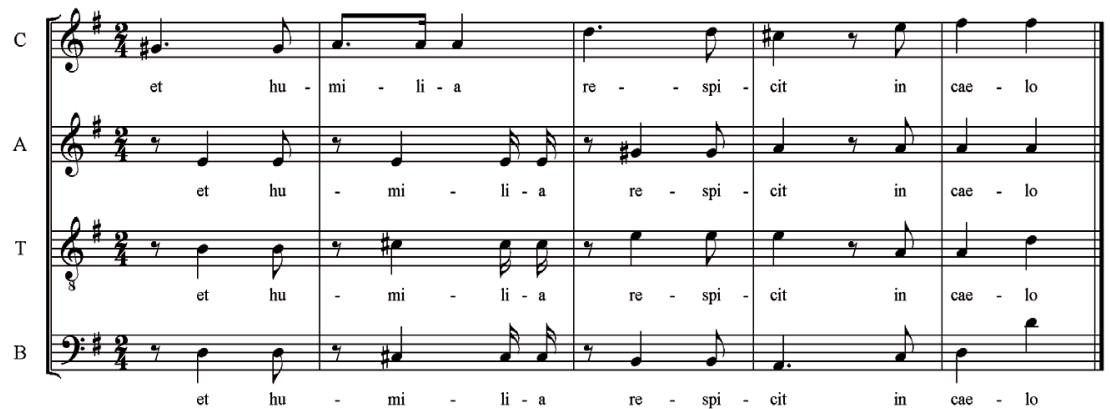

Przykład 26. Pernecker, Vesperae Dominicales, Laudate pueri, t. 34-38. 


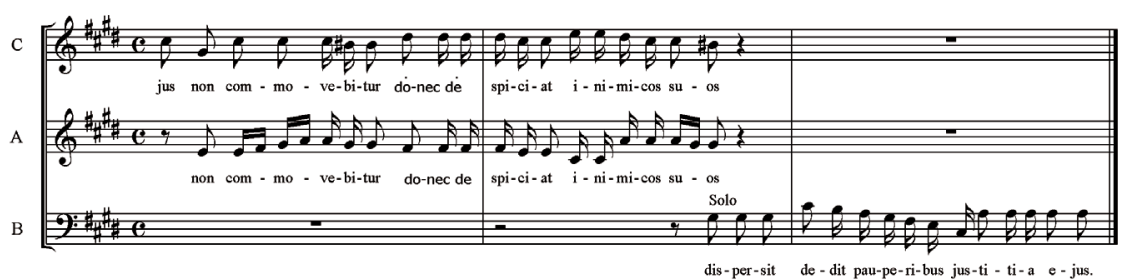

Przykład 27. Neumann, Vesperae de Confessore, Beatus vir, t. 20.

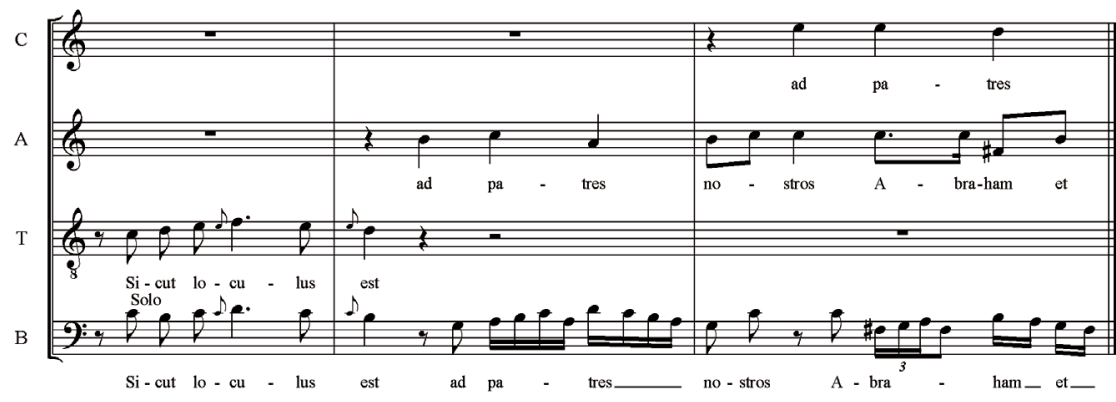

Przykład 28. Neumann, Vesperae de Confessore, Magnificat, t. 43-45.

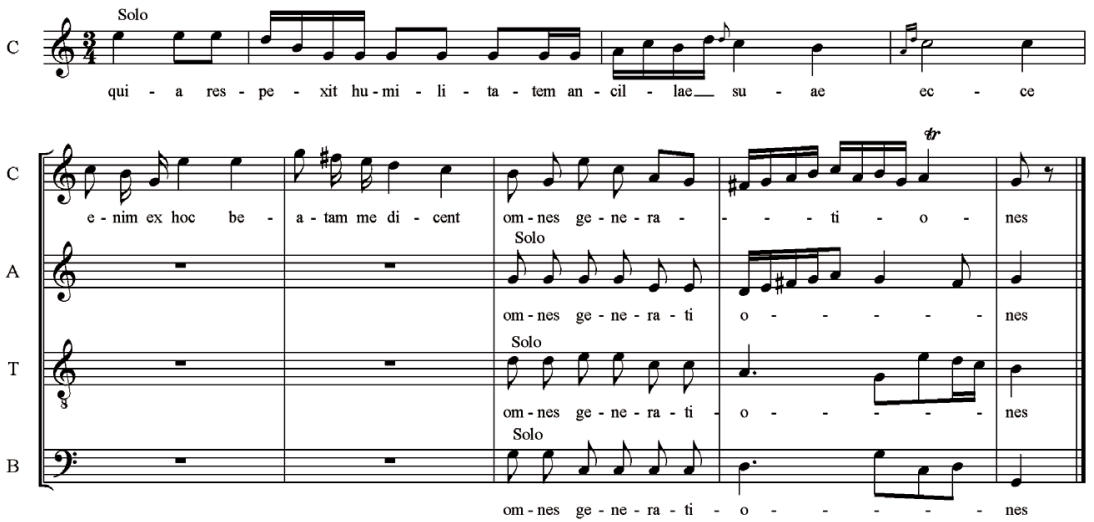

Przykład 29. Neumann, Vesperae de Confessore, Magnificat, t. 6-14.

funkcję pełnią szybkie pochody pasażowe w pierwszych taktach: „Laudate Dominum" (przykład 34). Z innych rozwiązań ilustracyjnych w warstwie akompaniamentu wymienić można triolę, która tworzy muzyczną interpretację jedności Trójcy Świętej: „et Spiritus Sancto” (vlno I, przykład 35). 


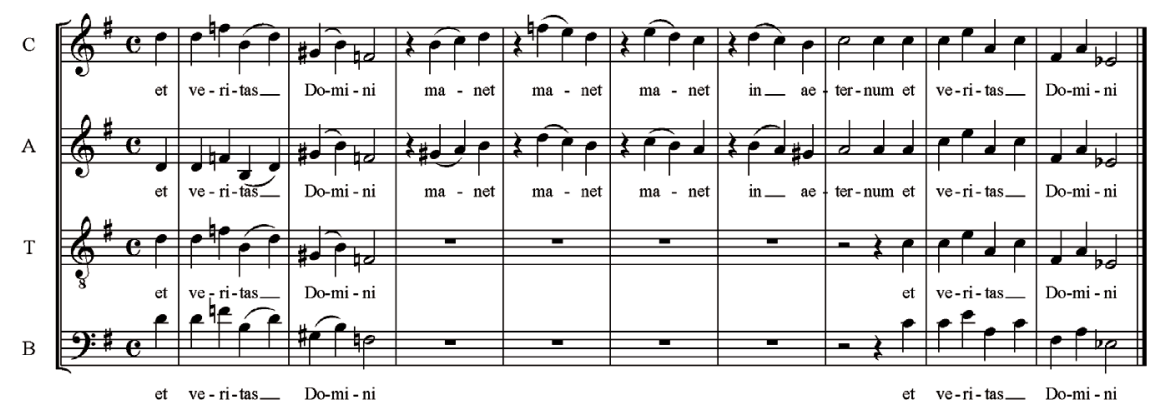

Przykład 30. Pernecker, Vesperae Dominicales Laudate dominum, t. 24-33.

\author{
$\mathrm{C}$
}

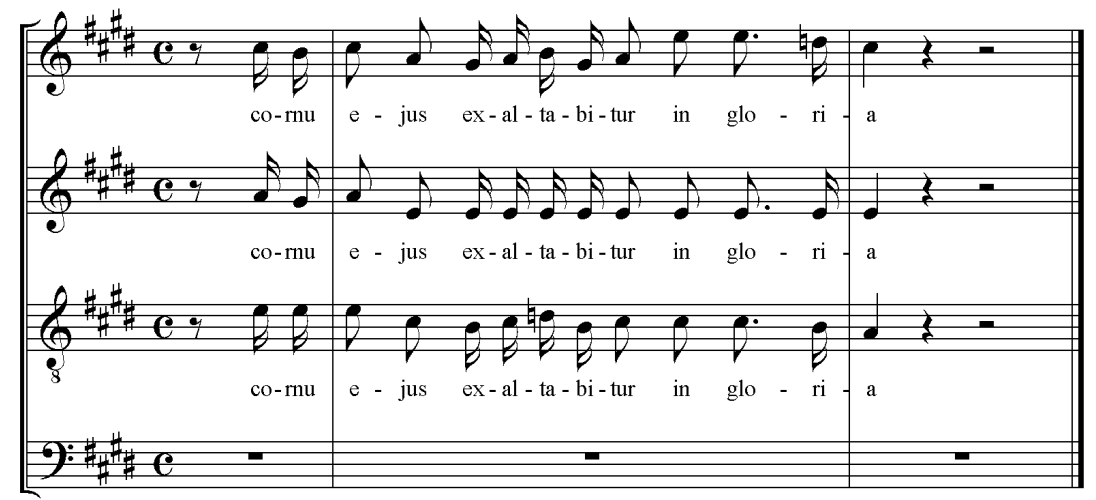

Przykład 31. Neumann, Vesperae de Confessore, Beatus vir, t. 21-23.

b) Afekty cierpienia i smutku.

Figury wynikające z kierunku linii melodycznej wykorzystane zostały także w muzycznej interpretacji uczuć negatywnych. Za pomocą catabasis uwypuklono tekst wyrażający lęk przed Bogiem: „timor Domini” (Neumann Vesperae de Confessore, Confitebor, t. 34) lub zapadającą ciemność: „forsitan tenebrae conculcabunt me” (przykład 36). Opadający kierunek linii melodycznej oddaje zarówno złość grzesznika: „peccatos videbit et irrascentur” (przykład 37), jak i uniżenie Maryi: „Quia respexit humilitatem” (przykład 38).

$\mathrm{Z}$ muzycznym obrazem cierpienia związane są przede wszystkim figury emfatyczne, które wykorzystują skoki o interwały zabronione przez prawidła kontrapunktu, a także łamiące diatonikę linii melodycznej. Liczne przykłady saltus duriusculi znaleźć można nad słowami ewokującymi ból, cierpienie lub strach: „rogate quae ad pacem” (figura pełni także funkcję eksklamacji, przykład 39), „confregit” 


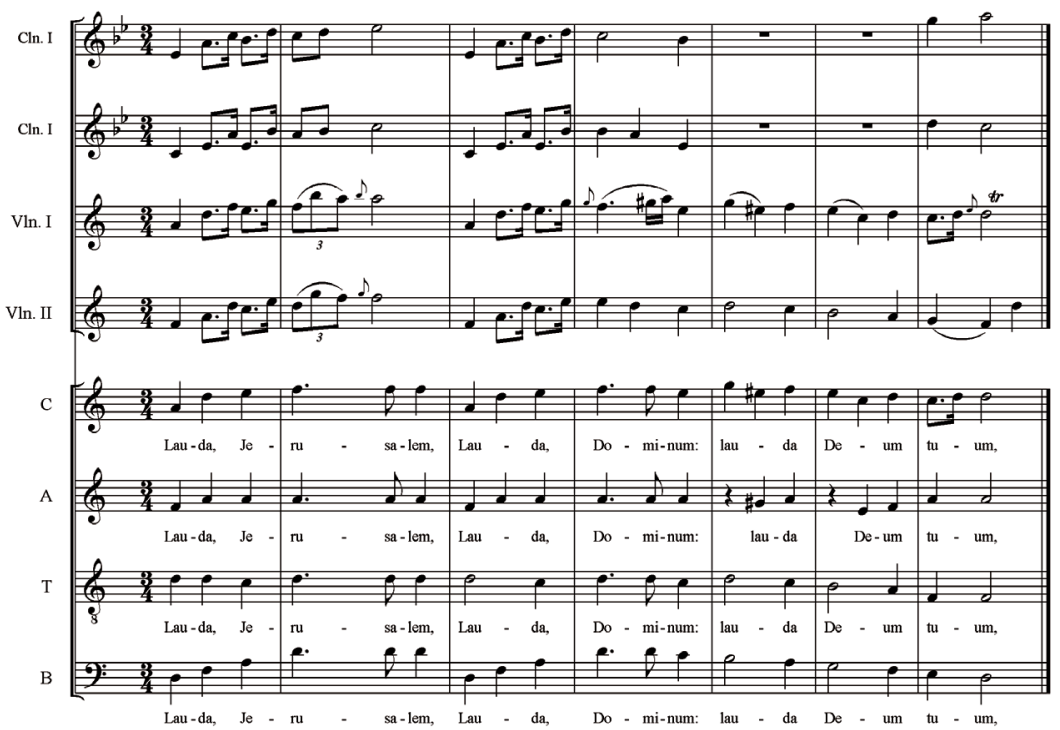

Przykład 32. Żebrowski, Vesperae D, Lauda Jerusalem, t. 17-23.
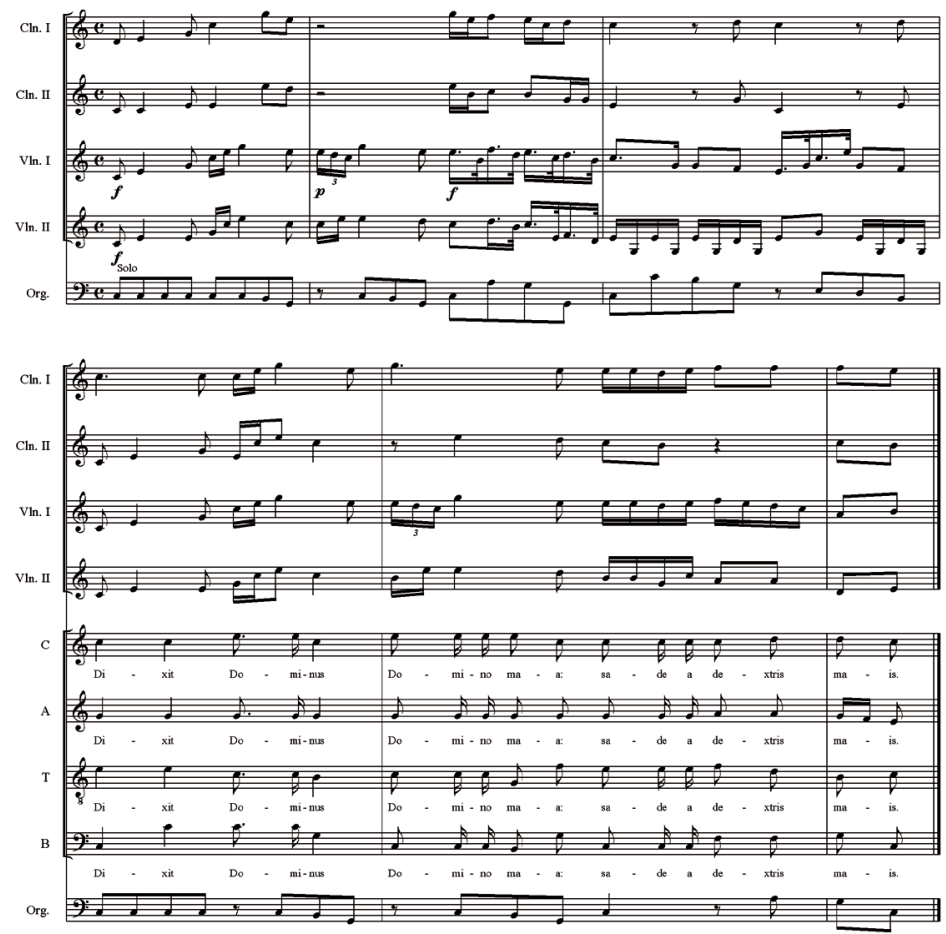

Przykład 33. Neumann, Vesperae de Apostolis, Dixit Dominus, t. 1-6. 

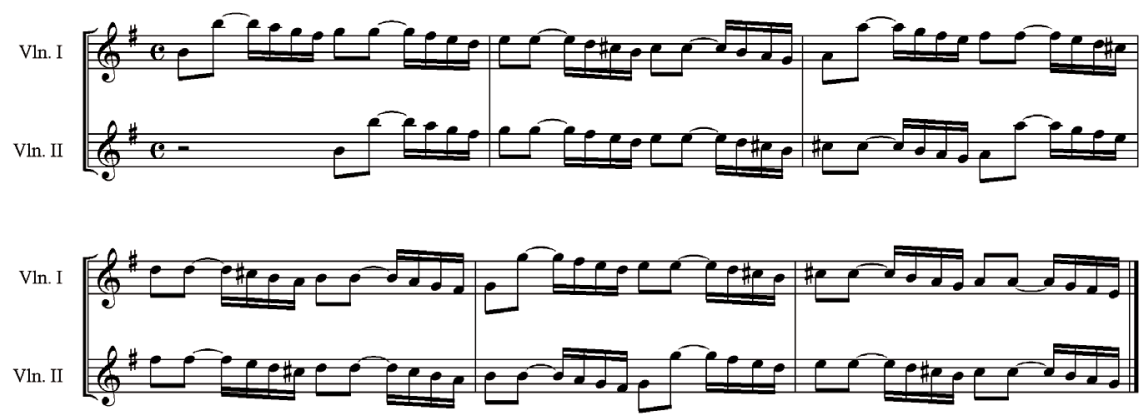

Przykład 34. Żebrowski, Vesperae D, Laudate Dominum, t. 11-16.

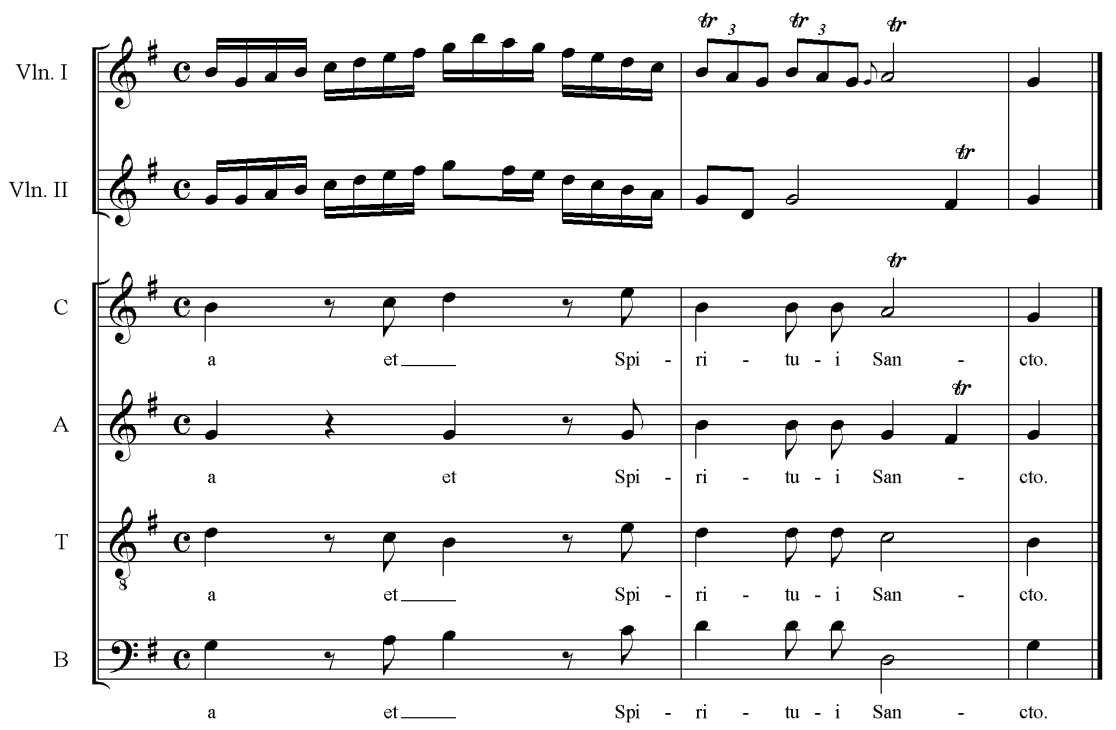

Przykład 35. Żebrowski, Vesperae D, Laudate Dominum, t. 33-35.

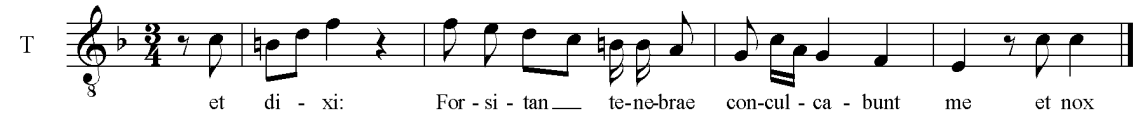

Przykład 36. Neumann, Vesperae de Confessore, Domine probasti, t. 33-37.

(liczne alteracje i postępy chromatyczne, przykład 40), „irrascentur dentibus” (4<, Neumann Vesperae de Confessore, Beatus vir, t. 24), „nox” (przykład 41), „die irae suae” (4<, Neumann Vesperae de Apostolis, Dixit Dominus, t. 36), „filii hominum non mortui" ( $4<$, pojawia się także kształt nasuwający skojarzenia z figurą krzyża, przykład 42). Innym środkiem ewokującym afekty negatywne są fragmenty z postępami chromatycznymi, nasuwającymi skojarzenia z figurą pathopoeia oraz passus duriusculus. Nie zawsze postać ustępów chromatycznych przyjmuje dokładny 
B

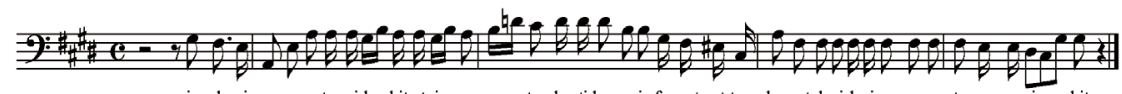

in glo-ri - a peccator vide - bit et $\mathrm{i}$ - ras-ce - tur den-ti-bus surs fremet et ta = beccet desiderium pecca - to-rum pe-ri - bit

Przykład 37. Neumann, Vesperae de Confessore, Beatus vir, t. 22-26.

$\mathrm{C}$

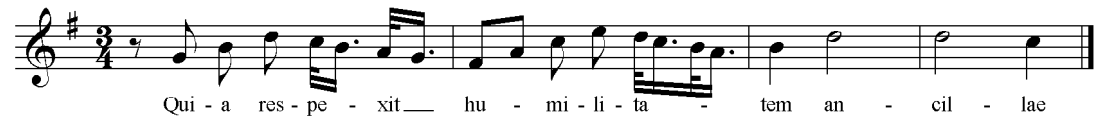

Przykład 38. Żebrowski, Vesperae D, Magnificat, t. 59-62.

$\mathrm{C}$

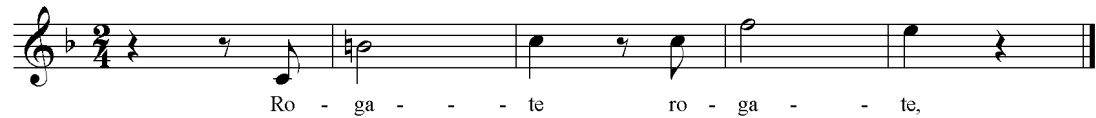

Przykład 39. Żebrowski, Vesperae D, Laetatus sum, t. 48-52.

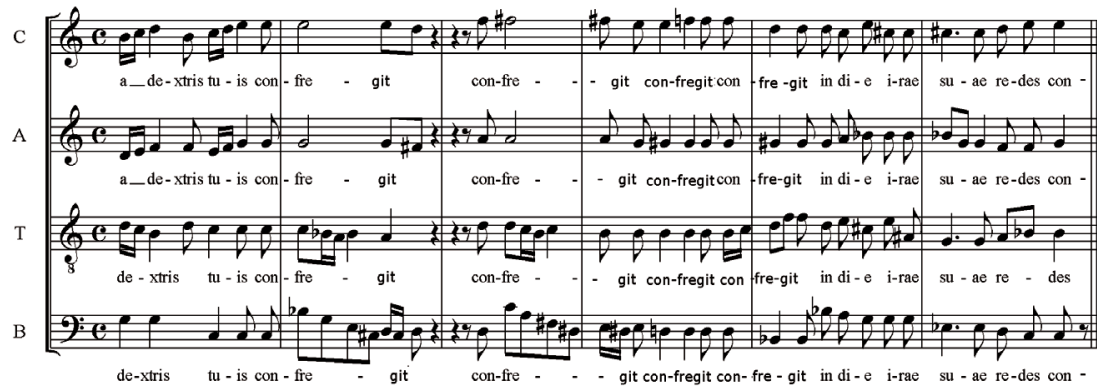

Przykład 40. Neumann, Vesperae de Confessore, Dixit Dominus, t. 32-37.

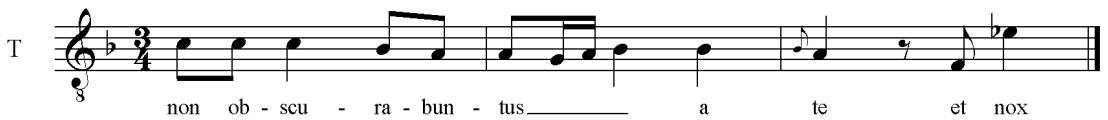

Przykład 41. Neumann, Vesperae de Confessore, Domine probasti, t. 66.

kształt wymienionych figur, jednak intencja twórcy jest oczywista. Wymienione figury oddają bojaźń przed Bogiem: „timentibus eum” (przykład 43), miłosierdzie: „misericordia eius” (przykład 44) oraz łzy: „lacrimis” (przykład 45).

Moc Boga, rozproszenie pysznych oddane zostały za pomocą szybkiego pochodu dźwięków - tiraty „dispersit potentes” (I i II vlno, przykład 46), „Dominus iuravit" (przykład 47). 
C

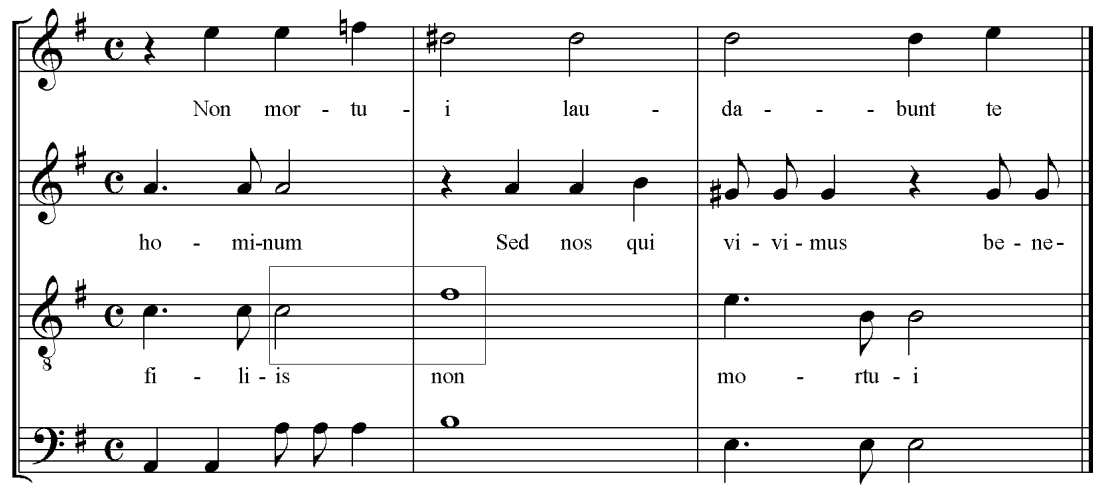

de - dit fi - li - is non

mor $\quad-\quad$ tu $-\mathrm{i}$

Przykład 42. Pernecker, Vesperae Dominicales, In exitu Israel, t. 102-104.

C

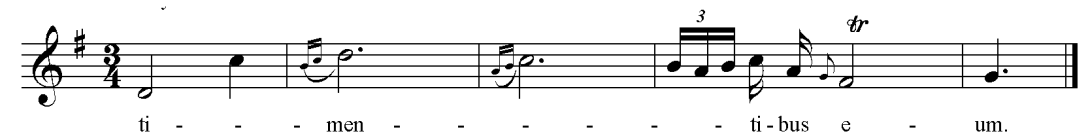

Przykład 43. Żebrowski, Vesperae D, Magnificat, t. 107-111.

$\mathrm{T}$

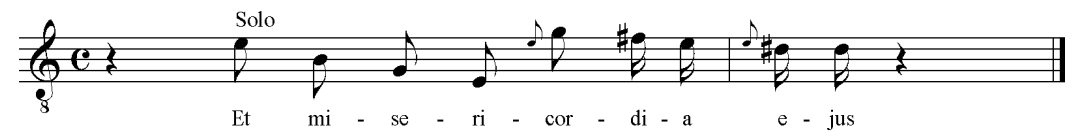

Przykład 44. Neumann, Vesperae de Apostolis, Magnificat, t. 23-24.

C
A
T
B

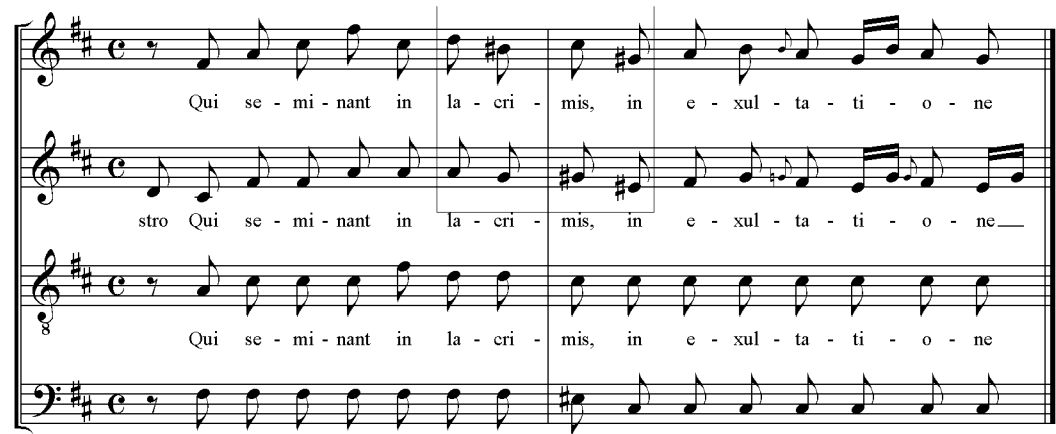

Qui se - mi - nant in la - cri - mis, in e - xul - ta - ti - o - ne

Przykład 45. Neumann, Vesperae de Apostolis, In convertendo, t. 30-31. 
B

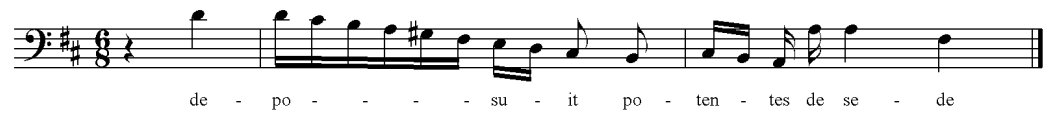

Przykład 46. Neumann, Vesperae de Confessore, Magnificat, t. 27-29.

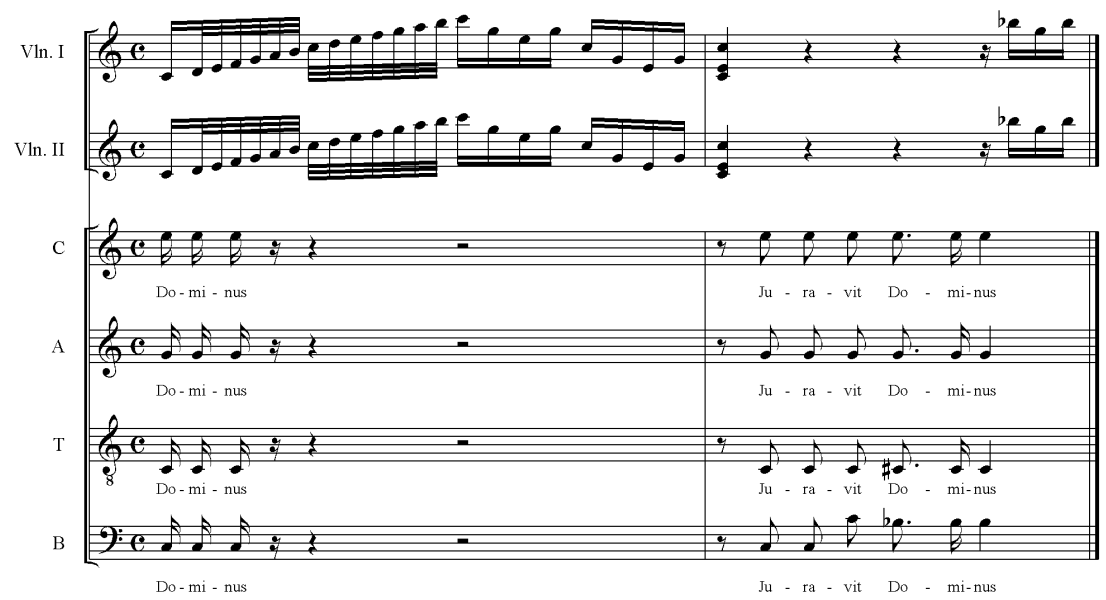

Przykład 47. Pernecker, Vesperae de Confessore, Dixit Dominus, t. 14-15.

Z innych rozwiązań zauważyć można zmianę trybu na molowy: „judicabit in nationibus” (przykład 48), także tercji trójdźwięku „converte” (przykłady 49 a i b) oraz mors (przykład 50). W partii instrumentalnej strach i drżenie przez obliczem Najwyższego ilustrują przednutki „timentibus” (por. przykład 43). Podobny afekt wyrażony jest za pomocą redukcji obsady: „sanctum terrible nomen” (przykład 51).

$\mathrm{Na}$ podstawie przeprowadzonej analizy nieszporów skomponowanych dla kapeli Ojców Paulinów na Jasnej Górze wynika, że ich twórcy znali obowiązujące w XVIII-wiecznej kompozycji zasady retoryki muzycznej. W każdym z cyklów wyróżnić można rozwiązania tradycyjne, stosowane w ówczesnej praktyce, ale także nowe środki związane z estetyką doby galant.

W badanych kompozycjach opracowane zostały psalmy wykonywane w trakcie nieszporów niedzielnych oraz w święta Apostołów i Wyznawców. Jedynie cykl autorstwa Briknera zawiera kompozycje, z których ułożyć można kilka zestawów na różne uroczystości kościelne.

Teksty psalmów zawierają afekty radosne (pochwalne) oraz emocje wyrażające smutek (cierpienie) spowodowany przez grzech. Uwielbienie jest cechą kantyku Magnificat - pieśni dziękczynnej Matki Syna Bożego za otrzymaną od Boga łaskę. 


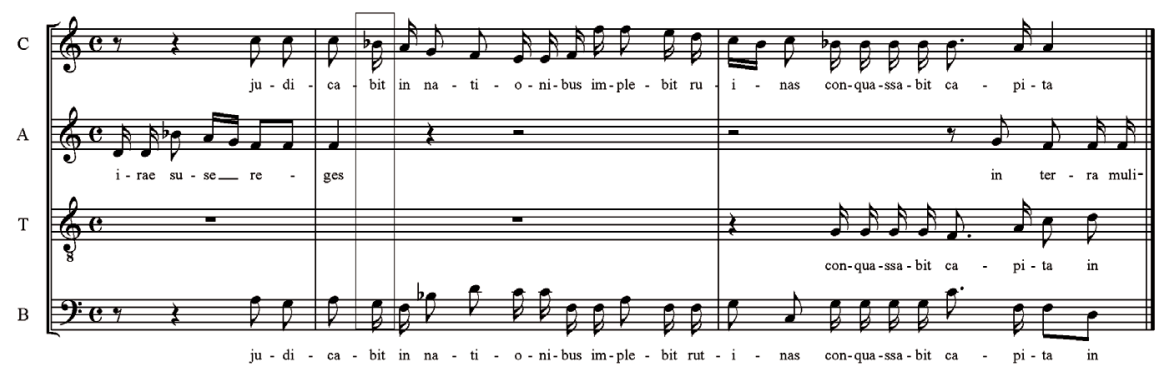

Przykład 48. Neumann, Vesperae de Confessore, Dixit Dominus, t. 17-19.

A
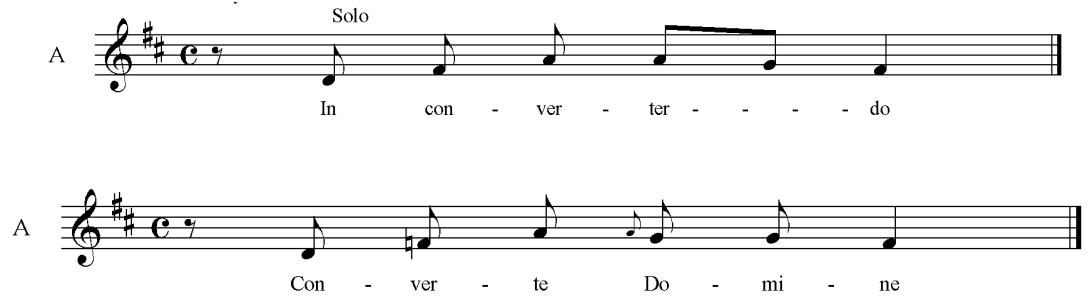

Przykład 49. Neumann, Vesperae de Apostolis, In convertendo, a) t. 2; b) 23.

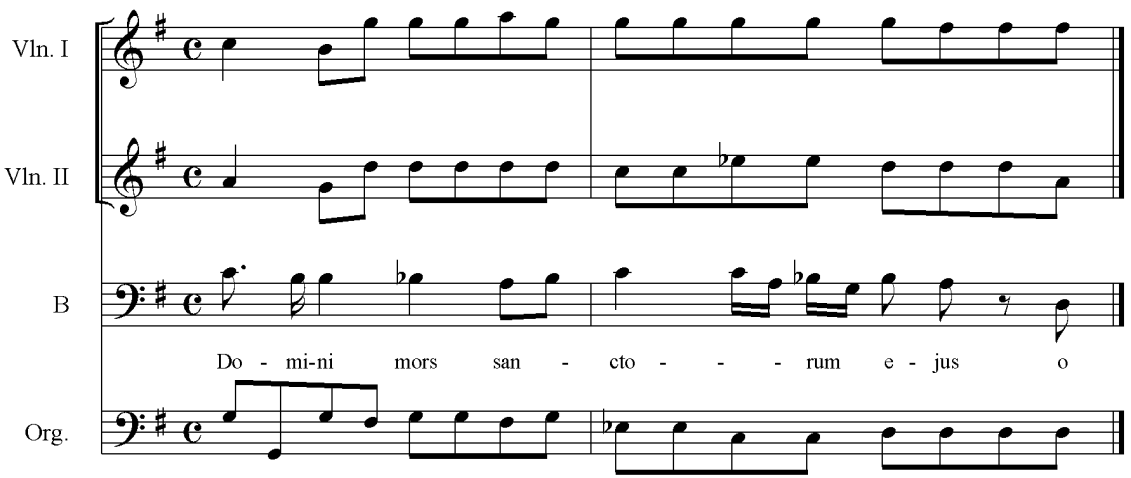

Przykład 50. Neumann, Vesperae de Apostolis, Credidi, t. 25-26.

We wszystkich tekstach oprócz dominującego afektu eksponowane są także inne nastroje występujące w krótkich odcinkach dzieła. Uzyskany w ten sposób efekt kontrastu służy potęgowaniu napięcia oraz dramaturgii formy. 


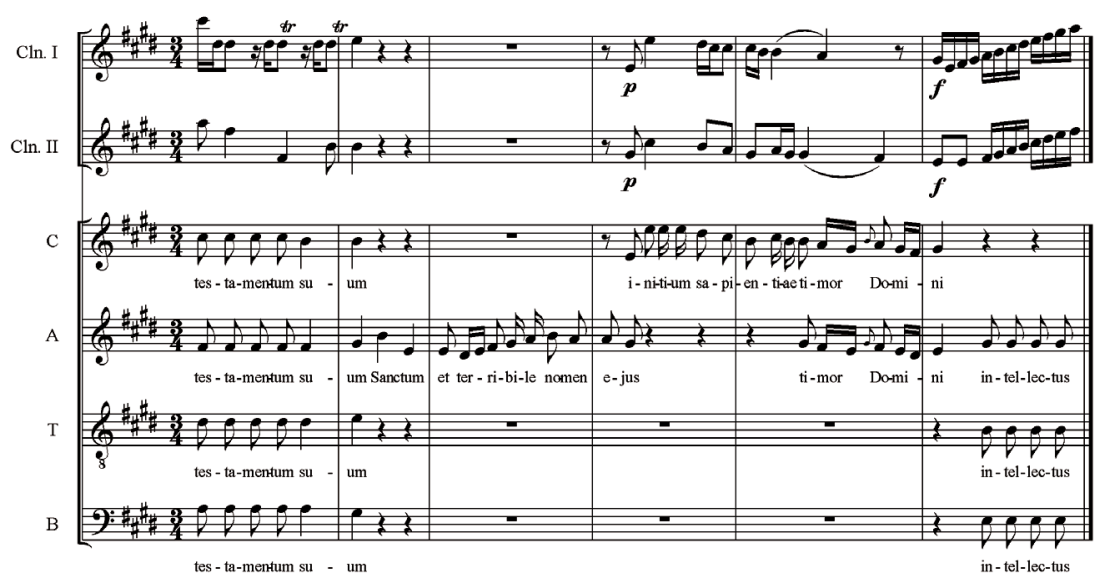

Przykład 51. Neumann, Vesperae de Confessore, Confitebor, t. 30-35.

Opracowanie muzyczne na ogół wiernie oddaje nastroje ewokowane w psalmach. W celu podkreślenia afektów kompozytorzy posługiwali się zmianami w obsadzie, kontrastach fakturalnych (arie, duety, fragmenty instrumentalne) oraz wykorzystanych tonacjach. Innym rodzajem środków ilustracyjnych są charakterystyczne konstrukcje dźwiękowe, które przez teoretyków muzyki skodyfikowane zostały jako figury retoryczne. Występująca nad istotnym słowem (verba affectorum) figura podkreślała jego znaczenie, wzmacniając jednocześnie ewokowany nastrój. Jednak nasycenie nieszporów jasnogórskich rozwiązaniami tego typu nie jest duże. Ze stosowanego w baroku katalogu można wyróżnić figury związane z ruchem głosów (anabasis i catabasis), a także skoki lub przejścia z wykorzystaniem dysonansów (saltus i passus duriusculi). Częstą praktyką było wyróżnianie słów przez rozbudowane melizmaty lub kontrast rejestrów, zmiany faktury (solo-tutti) czy rytmy punktowane (charakter fanfarowy).

Wykonywane przez paulińską kapelę nieszpory w pełni zasługują na uwage współczesnych wykonawców i włączenie części opracowanych psalmów do programów koncertowych. Idealnym rozwiązaniem byłoby przywrócenie opisywanym tutaj kompozycjom liturgicznego charakteru, być może także w trakcie mszy lub nabożeństw okolicznościowych. Dzieła kompozytorów jasnogórskich są przede wszystkim dziedzictwem narodowym i cennym świadectwem polskiej kultury muzycznej. 


\begin{abstract}
Abstrakt
Opracowania tekstów nieszpornych stanowiły drugą, obok mszy, grupę utworów chętnie podejmowanych przez kompozytorów tworzących na potrzeby Kościoła. Celebrowanie tej części officium divinum zyskało w ciągu wieków bogatą oprawę muzyczną, zwłaszcza w rycie monastycznym. Szczególny charakter miały vesperae na Jasnej Górze, gdzie codziennej modlitwie zakonników towarzyszyła paulińska kapela. Repertuar tego zespołu obejmował m.in. kompozycje twórców związanych z Częstochową, pełniących w klasztorze funkcje kapelmistrzów lub instrumentalistów.

Artykuł prezentuje dzieła siedmiu kompozytorów związanych z Jasną Górą w XVIII wieku. Materiał przeanalizowano pod względem związków tekstu liturgicznego z oprawą dźwiękową, będącego kluczowym zagadnieniem ówczesnej sztuki kompozycji. Analizowane utwory wykazują cechy znamionujące twórców doby wczesnego klasycyzmu, chociaż nadal obecne są w nich środki charakterystyczne dla barokowych retorów. Jasnogórskie nieszpory są cennym świadectwem kultury dawnej Polski - jednym z nielicznych zabytków, które przetrwały do naszych czasów.
\end{abstract}

Stowa kluczowe: Jasna Góra, nieszpory, retoryka muzyczna, liturgika, historia muzyki polskiej

\title{
Abstract
}

Musical illustration of the text in the 18th century Vesper cycles by the composers of Jasna Cióra Monastery

The Vespers attracted the interest of many church composers and were - apart from the Mass - the second most frequently chosen service text. The musical setting of this part of officium divinum became richer in the course of time, especially in the monastic rite. The Vespers of Jasna Góra were of special nature since the prayer of the monks was accompanied by the Pauline monastery music ensemble. Its repertoire included works by composers connected with Częstochowa, who were instrumentalists or kapellmeisters in the monastery.

The article presents seven composers connected with Jasna Góra in the 1700's. The material was analyzed in terms of the relationship between the liturgical text and the musical setting, which was the very core of the 18 th century art of composition. The musical works studied show features characteristic for the music of early Classical period, at the 
same time retaining some elements typical of the Baroque rhetoric. The Vespers of Jasna Góra are valuable evidence of Polish cultural heritage - one of the few preserved works of this kind.

Keywords: Jasna Góra, Vespers, music rhetoric, Liturgy, history of Polish music

\section{Bibliografia}

Bartel D., Handbuch der musikalischen Figurenlehre, Laaber 1985.

Evangelisches Kirchenlexikon. Internationale theologische Enzyklopädie, hrsg. E. Fahlbusch, H. Brunotte, O. Weber, t. 1-5, Göttingen 1986.

Gładysz J., Nieszpory-wokalno-instrumentalna forma w polskiej muzyce religijnej XVIII w. na przyktadzie twórczości S. F. Lechleitnera, „Roczniki Teologiczno-Kanoniczne” 34 (1987) z. 7, s. 339-345.

Harper J., Formy i uktad liturgii zachodniej od X do XVIII w., tłum. M. Kowalska, Kraków 1997.

Jasiński T., Polska barokowa retoryka muzyczna, Lublin 2006.

Patalas A., Muzyka jasnogórska: completorium o. Eryka Briknera na tle kompozycji Szarzyńskiego i Gorczyckiego, w druku.

Patalas A., Wstęp, w: E. Brickner OSPPE, Completorium, red. A. Palatas, Kraków 2006, s. 3-5.

Pismo Święte Starego i Nowego Testamentu, Warszawa 1980.

Podejko P., Kapela wokalno-instrumentalna na Jasnej Górze, Warszawa 2001 (Studia Claromontana, 19).

Podejko P., Katalog tematyczny rękopisów i druków muzycznych kapeli wokalno-instrumentalnej na Jasnej Górze, Warszawa 1992 (Studia Claromontana, 12).

Roche J., Musica diversa di Compietà: compline and its music in seventeenth-century Italy, „Journal of the Royal Musical Association”, t. 109 (1982) 1.

Sadzik J., Wstęp, w: Księga psalmów, tłum. Cz. Miłosz, Paryż 1982, s. 9-42.

\section{Rękopisy muzyczne}

Brikner Eryk, Vesperae pro toto Ao. | Canto Basso |Violinis 2bus |

Con $\mid$ Organo |Authore R. P. Rico Brykner | ord S. P Primi Eremitae | Pro Horo

Musico Ecclesiae Parochialis Kłob.|Canonicum Reg. Lat. Ao 1794|Od P. Chwasteckiego | Organisty Kłobuck., AJG III-50

Neumann Wawrzyniec, Vesperae de Apostolis in C | a | canto Alto | Tenore Basso

|Violino Primo | Violino Secondo | Clarino Primo |Clarino secondo |

Tympano Organo Violone, AJGII-184 
Neumann Wawrzyniec, Vesperae de Confessore in E | a $\mid$ Canto Alto | Tenore Basso |Violino Primo |Violino Secondo |Clarino Primo | Clarino

Secondo | Tympano | Con | Organo. | Authore Perneckher C.M.C.22, AJG II-197

Neumann Wawrzyniec, Vesperae de Confessore in D | a $\mid$ Canto Alto|Tenore

Basso. | Violino Primo. | Violino Secondo | Clarino Primo. | Clarino

Secondo | et | Organo. |Auth: Neümann., AJG III-953

Pernecker Franciszek, Vesperae de Confessore «in C» $\mid$ a

Stromenti | Canto Alto | Tenore

Basso | II Violini | II Clarini | Con Organo | Pro Choro | Clari

Montis | Częstochoviensis | Authore Francesco Perneckher., AJG II-195

Pernecker Franciszek, Vesperae Dominicales a 9 Stromenti|Canto, Alto, Tenore,

Basso. |2. Violini| 2. Clarini. | Con | Organo| Pro Choro Clari Montis C. Nro 34|Authore Francesco Perneckher., AJG II-196

Żebrowski Marcin Józef, Vesperae in D | cum Variis psalmis |a|Canto Alto, Tenore,

Basso | Violinis 2bus | Clarinis 2bus | con | Organo et Violone. | Auth. Żebro., AJG III-753

\section{Wydania nutowe}

Gorczycki G. G., Utwory wokalno-instrumentalne, red. Z. M. Szweykowski, Kraków 1995 (Monumenta Musicae in Polonia, seria A).

Roche Jerome, Musica diversa di Compietà: compline and its music in seventeenth century Italy, „Journal of the Royal Musical Association”, t. 109 (1982), s. 60-79.

Żebrowski M., Vesperae in D, Kraków 2008. 